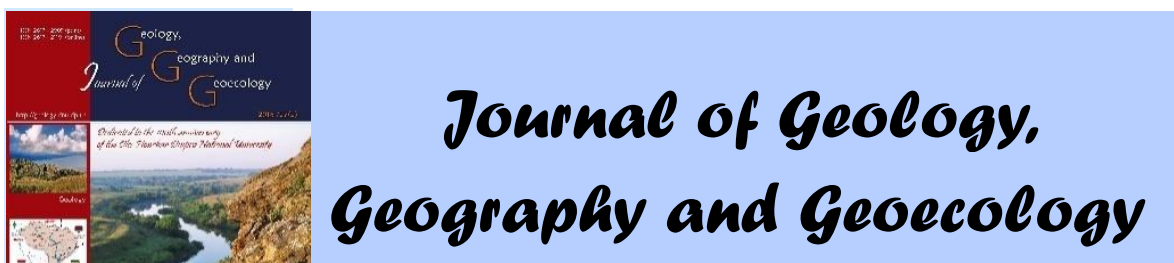

Journal home page: geology-dnu-dp.ua

\title{
Geological history of the Dnipro Rapids from Paleogene to Holocene
}

\author{
Volodymyr Manyuk
}

Oles Honchar Dnipro National University, Dnipro, Ukraine, e-mail: vgeoman@gmail.com

\section{Received 01.01.2019;}

Received in revised form 15.01.2019;

Accepted 20.02.2019

Yavornytsky. However, the geological studies were fragmented and there is no integrated source focussing on the geological structure of the Dnipro Rapids. We analyzed the results of the explorations of Valerian Domger, a famous researcher of the geology of Middle Prydniprovie.His routes investigated almost every corner of the then Katerynoslav governorate. After the creation of the Prydriprovie Regional Landscape Park (PRLP) in 2008 within the territory of part of the Dnipro Rapids, a question of restoration of its geological history should have emerged, but that has not happened. The year 2017 became the year of rebirth of the PRLP and recognition of geological component as the key feature of its restoration. The Pre-Cambrian stage of the geological history of the Naddniprovia Rapids is described in the author`s publication in early 2018, which focused on the most ancient history of the Rapids. The Phanerozoic Eon is analyzed in this work and focuses on the lithogical-facial peculiarities of the sedimentary rocks from Paleogene to Quaternary rocks on the basis of stratigraphic and paleontological data, according to which they have beendivided in detail. We determined the patterns in the structure of Quaternary deposits, the correlation of subaerial and subaquaticformations of different genetic types was made according to the use of the climatic-stratigraphic or paleoclimatic principle of division. The possibilities of creating a geological park on the basis of the"Dnipro Rapids" Regional Landscape Park ( "Dniprovi Porohy' RLP areexplored and substantiated.

Keywords: Dnipro Rapids, regional landscape park, geology, Paleogene Period, Neogene Period, Quaternary deposits.

\section{Геологічна історія «Дніпрових порогів» від палеогену до голоцену}

\author{
Володимир В. Манюк
}

Дніпровський національний університет імені Олеся Гончара, Дніпро, Украӥна, е-таil: vgeотап@gmail.com

\begin{abstract}
Анотація. Порожиста частина величної річки Дніпра впродовж тривалої історії іiі існування не тільки створювала проблему для судноплавства, але й приваблювала незвичними для степового Придніпров'я мальовничими скелястими ландшафтами. Вони не залишали байдужим жодного, хто міг їх спостерігати і захоплюватися їх красою. Історія зберегла немало літописних вражень від відвідування порогів з часів давньогрецьких філософів до неперевершених праць Дмитра Яворницького. Втім геологічні дослідження мали уривчастий характер і не існує жодного джерела, де цілеспрямовано розглядається геологічна будова саме дніпрових порогів. Проаналізовано результати досліджень відомого дослідника геології Середнього Придніпров'я Валеріана Домгера, маршрути якого не обминули майже жодний куточок тодішньої Катеринославської губернії. Після створення у 2008 р. Придніпровського регіонального ландшафтного парку (РЛП) в межах території більшої частини Дніпрових порогів мало б постати питання відтворення його геологічної історії, але цього не відбулося. Рік 2017 став на разі часом відродження РЛП та визнання вирішального значення в його становленні геологічної складової. Докембрійський етап геологічної історії Порожистого Наддніпров'я висвітлений на початку 2018 року у публікації автора, присвяченій найдавнішій історії порогів. Фанерозойський етап розглядається у даній роботі i стосується літолого-фаціальних особливостей осадових порід чохла від палеогенових до четвертинних, стратиграфічних i палеонтологічних даних, на яких спирається їх детальне розчленування. 3'ясовані закономірності будови четвертинних відкладів, здійснена кореляція субаеральних і субаквальних утворень різних генетичних типів на підставі використання клімато-стратиграфічного або палеокліматичного принципу розчленування. Обгрунтовано перспективи створення на основі РЛП «Дніпрові пороги» Геологічного парку.
\end{abstract}


Introduction. The issue of the development of rapids on the Dnipro, geological history of the Precambrian Period and the structure of the basement of the territory of the "Dniprovi Porohy" Regional Landscape Park was for the first time described in the article focused on the Precambrian history of the recently created park (Manyuk, 2017). Geological events of the following epochs were not so dynamic and not so prolonged compared to the Precambian Period, but their consequences have been preserved better and they are more practical for understanding and restoration of the paleogeographic conditions of those time periods, over which they formed. In the conditions of constant elevation of the Ukrainian Shield, descending of the Dnipro-Donetsk and Prychornomorska depressions, which border with the Shield, and therefore alternation of transgressive and regressive epochs over time, i.e. the epochs of incursion and recession of the sea, the sedimentary layer of Cenozoic rocks, the upper part of the Phanerozoic rocks, formed.

Review of the literature. Materials and methods of the study. Early data on the geological structure of the area between the Kremenchuh and Zaporizhia can be found in the works by V. Zuev (Zuev, 1787), J. A. Guldenstadt (Guldenstadt, 1879) andI. F. Levakovskij (Levakovskij, 1872). The first claim for about the Tertiary age of the rocks at the beginning of the section of the sedimentary layer from the studied territory was made by Frédéric DuBois de Montperreux during his journey to Kazakhstan (Dubois de Monperre, 1843). Borysiak N. D., an ordinary professor of the Kharkiv University, gave these rocks which he called aboveCretaceous rocks a more precise lithological as well paleontological characteristic (Borisyak,1867). In his researches, we can find the following conclusion: "Therefore the observations of Hoffmann, DuBois in Kyiv, Budzhak along the Dnipro gave Murchison a reason, on the basis of a prominent researcher Leopold von Buch, to accept the presence of Eocene rocks here" (Borisyak,1867). The survey by M. P. Barbot-de-Marni (Barbot-de-Marni, 1969) was of great importance for the development of the stratigraphy of the Cenozoic sedimentary deposits of southernUkraine.

It is not surprising that according to the scientist's contemporaries: "M. B. Barbot-deMarni is a teacher of practically all best geologists of the second half of the XIX century". He was the first to develop the stratigraphy of the Paleogene and Neogene rocks of the Ukraineplatform. The next important step in the study of the sedimentary formations of the Middle
Podniprovia were the works of a famous geologist and paleontologist O. V. Gurov "On the geology of Ekaterinoslav and Kharkov governorates", 1882. (Gurov, 1882)and"Geological description of the Poltava governorate" (Gurov, 1888). The author came to the conclusion that "the post-Cretaceous shallow water which existed over the sedimentation of phosphorite sands (the basal layer of Kyivska suite), changed in the mid Paleogene Period into a deep sea, from which marl was deposited, which resembled Cretaceous deposits". These rocks which are now considered within the Kyivska suite were found in the premouth part of the Synelnykivska paleodepression and do not occur south of the Zaitsevo village.

However, the depression itself in the lower part is filled with Mandrykivski layers, deeply cuts into the rocks of the Precambian basement and with its upper reach intersects the borders of "Dniprovi Porohy" RLP between theTavolga water small rapid and Lyshnii Rapid (Fig. 1). O. V. Gurov recognizes the Eocene age of these rocks and compares them to the nummulitic strata in the Crimea and the Caucasus, and also with the middle and lower Eocene rocks of the London Basin (Gurov, A.V. 1882). The abovementioned Mandrykivski layers were discovered by Valerian Domger, one the most famous explorers of South Ukraine. In his work of 1902 "Geological studies in Southern Russia" (Domger, 1902), he provided the description of a section of boreholes bored during the projection of the Kryvy Rih Raiway along the Katerynivsky Bridge, but no fossil fauna was discovered then. The fauna was discovered, however, in the same year, in 1882, when the foundation for the supports and for the construction of caissons were being laid, the rocks were being thrown, according to Domger, straight into the water. Later, a succesful combination of cuircumstances took place, about which Domger wrote: "If in this place, where the bridge is being built, there was no sandy island, where four caissons are placed, we woud not have discovered whether the abovementioned rocks (glauconite sands and gritty clay) include any organic remains, because everything extracted from the caissons was usually thrown away straight into the water" (Domger,1902).

Sokolov M. O., who in 1894 made a monograph description of the fossil fauna collected by V. O. Domger, mentioned that "Another thing we were lucky with was that in the year of constructing the bridge, Domger happened to be in Katerynoslav, and was lucky to collect such interesting fossils" (Sokolov,1894). A highly respected paleontologist came to the wrong conclusion that the age of the rocks which include 
this fauna was Lower Oligocene and corresponded to the time of accumulation of the Latdorf Stage beds in Germany. At the same time, previous analysis of various fossil fauna of the detritus sands allowed V. O. Domger to draw the conclusion that the layers which contain it, by time of deposition corresponded to Middle Eocene Period, the so called "large-fraction limestone" of the Paris Basin. Some time later, in 1886, during digginga water borehole in the residence of a German, A. A. Oswald, in Mandrykivka Sloboda, a layer of sand was found, which was overflowing with well preserved shells. A. V. Gurov, to whom A. A. Oswald gave a part of the collection of shells for study, classified the Mandrykivski sands as formations of the Eocene Period and

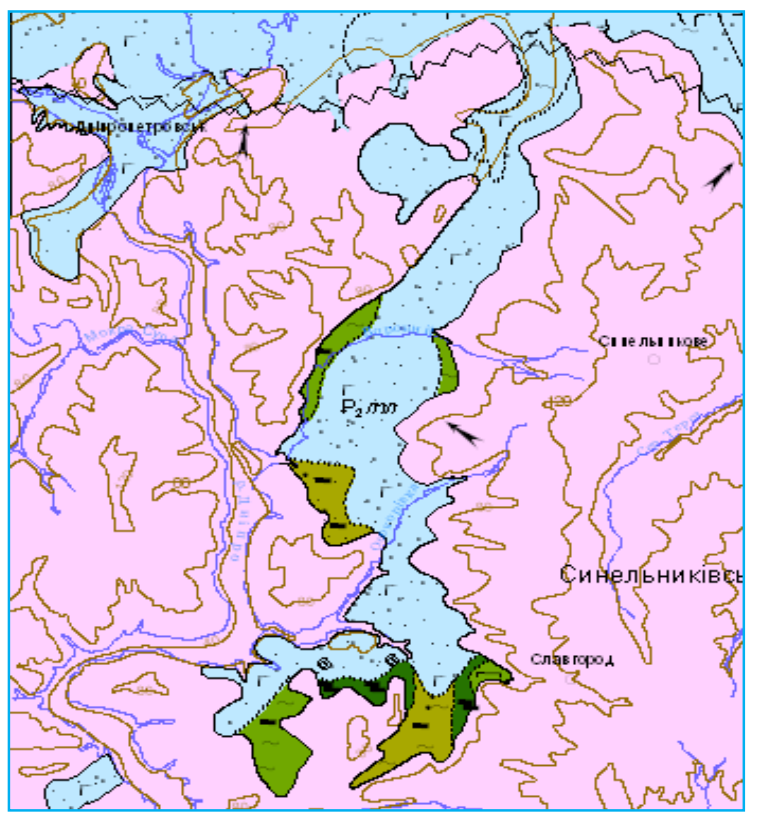

In 1947, on the basis of study of the flora collected during boring a shaft and borehole in the area which earlier belonged to A. A. Oswald, and also materials from other beddings, M. M. Kliushnikov came to the conclusion that the area of distribution of detritus lime-clayey sands with fossil fauna ranges far beyond Mandrykivka village. He also found numerous signs of the Upper-Eocene age of the Mandrykivski Layers and considered that the Oligocene age of the Latdorf Stage beds, incredibly similar to the Mandrykivski layers, should be reconsidered, which was performed later (Kljushnikov, 1950). An essential event in the history of the study of the age of the Mandrykivski Layers was determination of the age of the Latdorf sands in Germany as Late-Eocene, on the basis of studies by E. Krutzsch and D. Loch (Krutzsch, Lotsch, 1957). A new stage in the study of the Mandrykivski Layers began after a large area of them in the Rubalsky (Chaplynsky) Quarrywas considered them synchronous with the sands and loamy sands in Traktemyrivka and Buchak villages (Gurov, 1882). Later, the fauna of the Mandrykivski layers was studied by A. V. Faas (1894), P. A. Tutkovsky (1825), P. L. Ivanov, V. Slodkevich (1933) and it was proven that the detritus sands of Mandrykivka village and Monastyrsky Island and areas of the MerefaKherson Railway Bridge are one stratigraphic layer (Manyuk, 2012). In 1939, L. F. Lundershausen for the first time expressed theview that the Mandrykivski layers are a shallow water facies of the Upper Kyivsky Stage. Later this conclusion was proven in numerous studies by O. K. Kaptarenko-Chernousova, 1951).

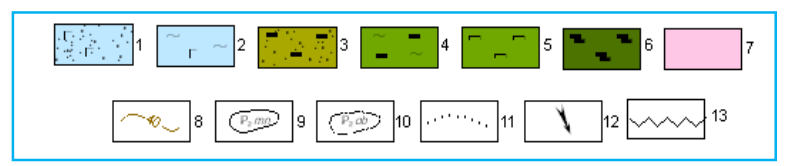

Fig. 1. Lithological-facies map of distribution of Upper Eocene deposits (the Obyhivska suite and the Mandrykivski Layers.

Coastal-marine facies: 1 - glauconite-quartzitic grey-green sands; 2 - glauconite-containing clays. Alluvial-lake facies: 3 - quartzitic, fine- and average-grained, and carbonaceous sands. Lake-swamp facies: 4 - carbonaceous clay; 5 secondary kaolin; 6 - brown coal. Other conventional signs: 7 - denudation area; 8 - stratoisohypses of the surface of PreOlihocene relief; 9 - border of distribution of the Mandrykivski Layers; 10 - border of distribution of the Mandrykivski Layers; 11 - facies borders; 12 - orientations of transfer of the terrigenous material

found. In 1975, M. F. Nosovsky, I. D. Konenkova et al. conducted an integrated paleontological study of different groups of the fossil fauna from the Mandrykivski Layers of the Quarry and two boreholes near the Quarry. The authors noted a significant similarity of the species composition of Foraminifera, Mollusca and nanoplanktonwith complexes determined earlier and designatedthe fauna-containing rocks to the NP zone (Martini,1971), which corresponds to the middle part of the Upper Eocene (Nosovskij, Konenkova, Barg, Bogdanovich, 1978).

In 2000, during GDP-200 (Geological additional study of areas)within the Dnipropetrovsk sheet, the author delt with the necessity of designating the Mandrykivski layers as a separate stratigraphic unit. Despite their extreme popularity, the layers, surprisingly, had no status. The Commission of Stratigraphic Classification into Nomenclature of the National Stratigraphic Committee of Ukraine considered 
the request of Pivdenukrgeologiia communal enterprise regarding designation ofthe Mandrykivski Layers and decided to approve the Mandrykivski Layers as a separate stratigraphic unit (Layers with geographic name) (protocol № 7, 06.12.2001).According to the content, within the Rybalsky Quarry and certain areas of most paleodepressions, the Mandrykivski Layers are carbonate-detritus rocks of light-grey-yellow coluor, slightly consolidated, cemented with thin sandy detritus, with large amount of fragments and intact shells of Bivalvia and Gastropoda mollusks, single and colonial corals, Bryozoa, with remains of sea urchins, teeth of sharks and spicules of spunges. A characteristic feature is the presence of a large amount of dense carbonate concretions (Fig. 2).
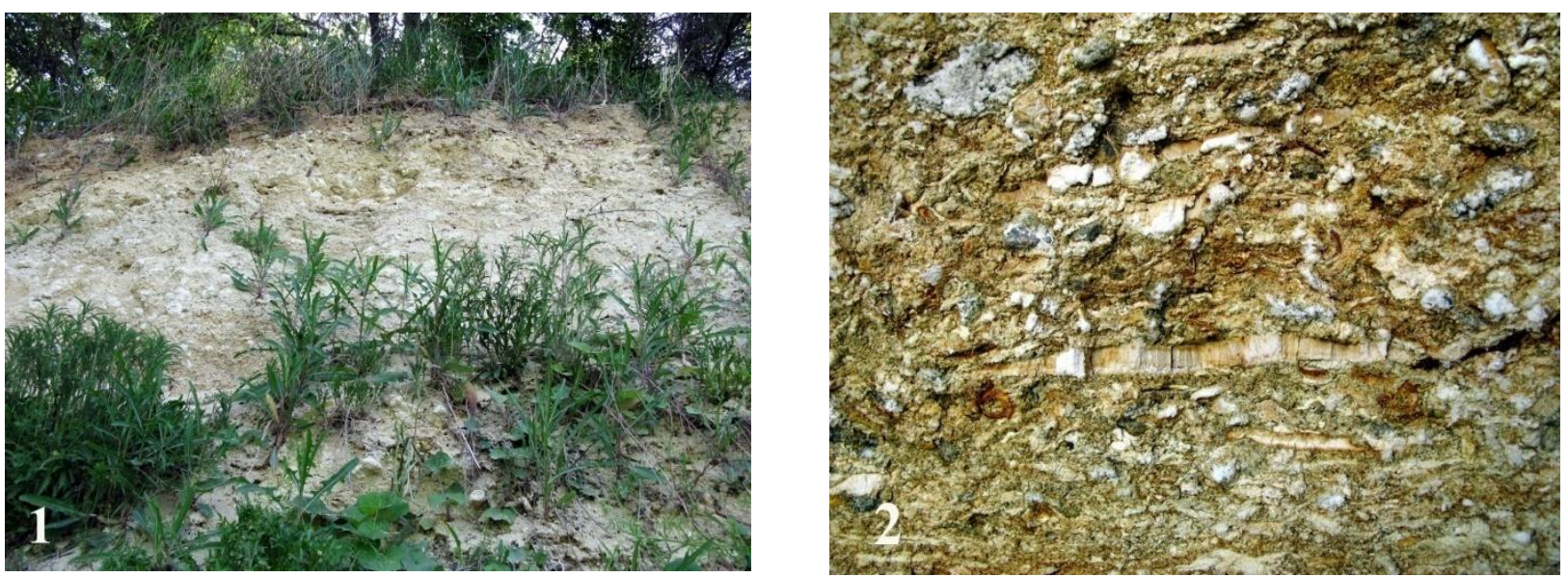

Fig. 2. Outcrops of the Mandrykivski Layers in the Rybalsky Quarry (1-layer with large amount of carbonate concretions; 2 - mostly detritus composition of the layers)

In the Synelnykovo Depression, in relation to the changes in the facial peculiarities of the section, in lithological aspect, a significant role is played by light grey-green-yellow and greenishgrey quartzitic sands with a notable amount of glauconite, fine-grained (to aleurite), with detritus of various fossil fauna. In peripheral areas, marine facies become alternated by lake-swamp facies and are represented by carbonaceous clays, secondary kaolin and lignite (Fig. 1). The

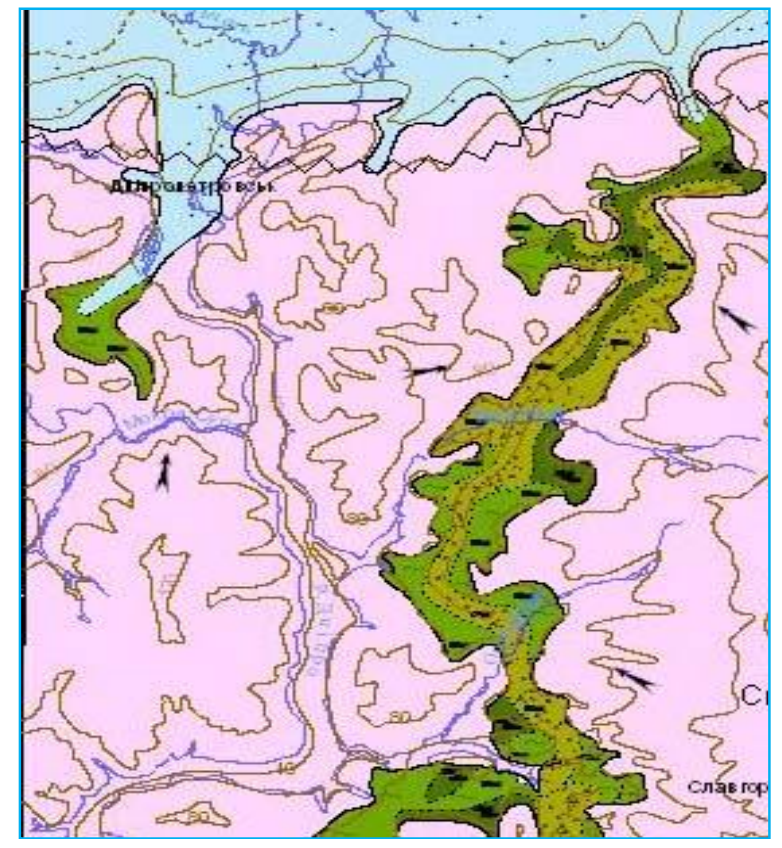

thickness of the Mandrykivski Layers ranges from 2 to $15 \mathrm{~m}$.

Results and their analysis. At the beginning of the Paleogene Period, the surface of the Ukrainian Shield was divided by numerous depressions or paleovalleys, through which the Cenozoic seas deeply entered into the structure. The oldest rocks of the platform cover, which fill the beds of the Mandrykivska and Synelnykivska paleodepressions, are terrigenous-carbonaceous sediments of the Buchatska series (Fig 3).

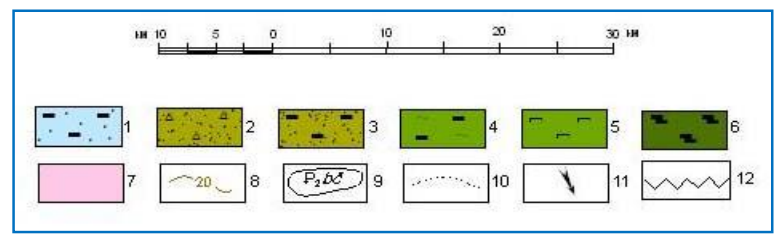

Fig. 3. Lithological-facies map of Middle Eocene sediments (Buchatska series).

Coastal-marine facies: 1 - quartzitic, glauconite-quartzitic fine- and large- grained sands with inclusions of brown coal material. Alluvial facies: 2 - fine-grained, quartzitic sands. Alluvial-lake facies: 3 - quartzitic, fine- and averagegrained, and carbonaceous sands. Lake-swamp facies: 4 carbonaceous clay; 5 - secondary kaolin; 6 - brown coal. Other conventional signs: 7 - denudation area; 8 stratoisohypses of the surface of pre-Kyiv period; 9 - borders of distribution of sediments of the Buchatska series; 10 facies borders; 11 - orientations of movements of terrigenous material; 12 - borders of structural-facies zones. 
They were studied in the boreholes due to having no outcrops to the surface. In the north part of the region, the section of the series is composed of an almost homogenous layer of shallow-water marine origin, which is embeded with unconformity on the eroded surface of Mesosoic and Cenozoic rocks. Carbonaceous-terrigenous sediments of paleovalleys which divide the surface of the Ukrainian Shield are embeded with unconformity on the crystalline rocks of the basement. They are characterized by significant mottling of the content with different overlapping of carbonaceous, kaolin and mixed clays, quartzitic carbonaceous and clayey sands with layers and lenses of brown coal. The upper part of the section contains carbonaceous clay with interlayers of brown coal of up to $4.6 \mathrm{~m}$ thickness. The middle of section is the most variable in composition and thickness. There is an approximately uniform ratio of sands and clay with variable extent of kaolin and carbonate. In the beds of the depressions, quartzitic carbonaceous sands and gravelites with thin interlayers of carbonaceous-kaolin clays dominate. It should be mentioned that in the peripheral areas of the depressions, sandy sediments are displaced and substituted by carbonaceous clay with lenses of brown coal.

Brown coal is distributed within the depression, is characterized by variable thickness and composition. It is often gritty, kaolin, with inclusions of lignite and interlayers and lenses of sands, clays and secondary kaolins. Thickness of carbonaceous stratas ranges $1-2 \mathrm{~m}$ to $14.8 \mathrm{~m}$, rarely up to $21 \mathrm{~m}$. The most carbonaceous is the largest paleovalley - Prydniprovska (Synelnykivska), within which two carbonaceous deposits are mined - Synelnykivske and Pervozvanivske.

Deposits of the Buchatska series are characterized by poverty of organic complexes in most of their range. In glauconite-quartzitic sands distributed in the area of Priadivka village, N. G. Savenko (Savenko, 1972) found a complex of Foraminifera, which includes: Spiroplectammina ex. gr. varieta $\mathrm{V}$ a s s., Bulimina mitzargiana $\mathrm{B}$ a 1 a $\mathrm{k}$ h m., B. arostrata B a 1 a $\mathrm{k}$ h m., Pseudoparella almaensis $\mathrm{S}$ a $\mathrm{n}$ e 1., which are characteristic of the Middle Eocene. In the undercarbonaceous layer of the Synelnykivska Depression, A. N. Krishtofovich identified: Miniphillum eleganse $\mathrm{E} \mathrm{t} \mathrm{t}$. $\mathrm{G}$ a $\mathrm{r}$ t, Mirica salicina, Driophillum de walquji $\mathrm{S}$ a $\mathrm{p}$., $D$. pavlogradense $\mathrm{K}$ r y s h t, D. palaeocastanea $\mathrm{S}$ a p., Bumelia minor U n g e r. and others, which allows one to considering the marine and continental facies of the Buchatska series as belonging to the Middle Eocene period. The facies conditions of accumulation of sediments of the Buchatska series within the paleodepressions were continental, comprising a sequence of alluvial, alluvial-lake and lake-swamp sediments characteristic of the Synelnykivska structuralfacies zone (SFZ). The thickness of the series' deposits is $25-30 \mathrm{~m}$; up to $45 \mathrm{~m}$ in the deepest areas of the paleodepressions.

The Bartonian stage of the studied territory is represented by the Kyivska suite. Terrigenouscarbonaceous sediments of the Kyivska suite are transgressively embeded with a wash out on the rocks of the Buchatska series, mostly within Novomoskovsk-Pavlohrad SFZ and fill the paleodepressions of the Ukrainian Shield. In the areas of the paleodepressions which intersect the territory of the "Dnipro Rapids" Regional Landscape Park deposits of the Kyivska suite are absent, except for small islands on its southern slope.

Obuhivska suite which corresponds to the Priabonian stage of the international scale, is a layer of only terrigenous rocks and corresponds to the former Upper Kyivska Subsuite. In 1984, V. Y. Didkovsky, V. Y. Zosimovych and others proposed a layer of rocks, which corresponds to the Kharkiv "stage", but ranked as series; and suggested to divide it into two suites: Lower, Upper Eocene, Obuhivska and Upper, LowerMiddle Oligocene, and Mezhuhirska. The proposition was accepted and approved by the Ukrainian Stratigraphic Committee in 1985. The Obuhivska suite is embedded between the surface of the crystalline basement, in the northern part between clearly faunistically characterized deposits of the Kyivska suite and glauconitequartzitic aleurites of the Mezhyhirska suite which overlaps it. Its contact places are not always clearly distinguished, which is conditioned by the similarity of the conditions of formation of the sediments, short breaks in the accumulation of sediments and, therefore, similarity of the lithological composition of the rocks. Within the territory of the Dnipro Rapids, the sediments of the Obuhivska suite are represented only by its facies analogue,that is the Mandrykivska suite, the history of studying which is described above in detail (Fig. 1, 2).

The Mandrykivski Layers contain fauna unique in number, diversity and preservation, which was studied in different years by A. V. Hurov, N. A. Sokolov, A. F. Faas, L. L. Ivanov, B. F. Meffert, O. K. Kaptarenko-Chornousova, M. M. Kliushnikov) and others. Over the later years, monographic study of Bivalvia was performed by V. P. Stefansky (Stefanskij, 1987), 
Gastropodawere studied by O. V. Amitrov (Amitrov, 1987), otolites - by Rozenberg A. (Rozenberg, 2001), etc.

Among the mollusk complexes, the most numerous areGastropoda, for which over 300 species of 60 families are recorded. The commonest are representatives of Neritopsis, Tectus, Cerithium, Turritella, Natica, Rostellaria, Volutilitres, Ancillaria, Mirta. The complex of Bivalvia comprises 80 species of 19 families, among which Glycymeris, Chata, Vulsella, Venericardia, Crassatella, Limopsis.are dominant.

In clayey-carbonaceous-detritus deposits of the Rybalsky Quarry, a complex of Foraminiferahas been found: Lagena Isabella O r b., Robulus inomatus O r b., Globulina gibba O r b., Guttulina irregularis O r b., Pirrulina sp., Cibicides carinatus $\mathrm{T}$ e $\mathrm{r}$ g., C. perlucidus $\mathrm{N}$ u t t, Alabamina almaensis $\mathrm{S}$ a m o i 1, Asterigerina rotula haeringensis $\mathrm{Luh} \mathrm{r}$. and others; nanophytoplankton: Isthmolithus recurvus Deflandre, Reticulofenestra umbilica $\mathrm{L}$ e v i n, Cyclococcolifhus formosus $\mathrm{K}$ a $\mathrm{m} \mathrm{t} \mathrm{r}$ e r, C. birtusus $\mathrm{M}$ u $11 \mathrm{e} \mathrm{r}, C$. pelagicus $\mathrm{W}$ a $11 \mathrm{ich}$, Discoaster saipanensis bramlette et $\mathrm{R}$ i e $\mathrm{d}$ e 1 and other; molluscsGlycymeris lunulatus N y st., $G$. deletus deletus $\mathrm{S}$ alander, Lymopsis striata R o u a l ta), Chama calcarata La marck, Crassatella lamellosa $\mathrm{L} \mathrm{a} \mathrm{m.} \mathrm{and} \mathrm{many} \mathrm{others.}$ The conducted paleontological studies proved a clear correlation of the deposits with fauna of the Mandrykivsky type with formations similar in lithological aspect and in fauna, which are distributed in the northern part of the Prychornomorska depression, which are mapped within the Alminska suite (Konenkova, 1995), Manyuk, 1996). Hypsometry of the surface of the

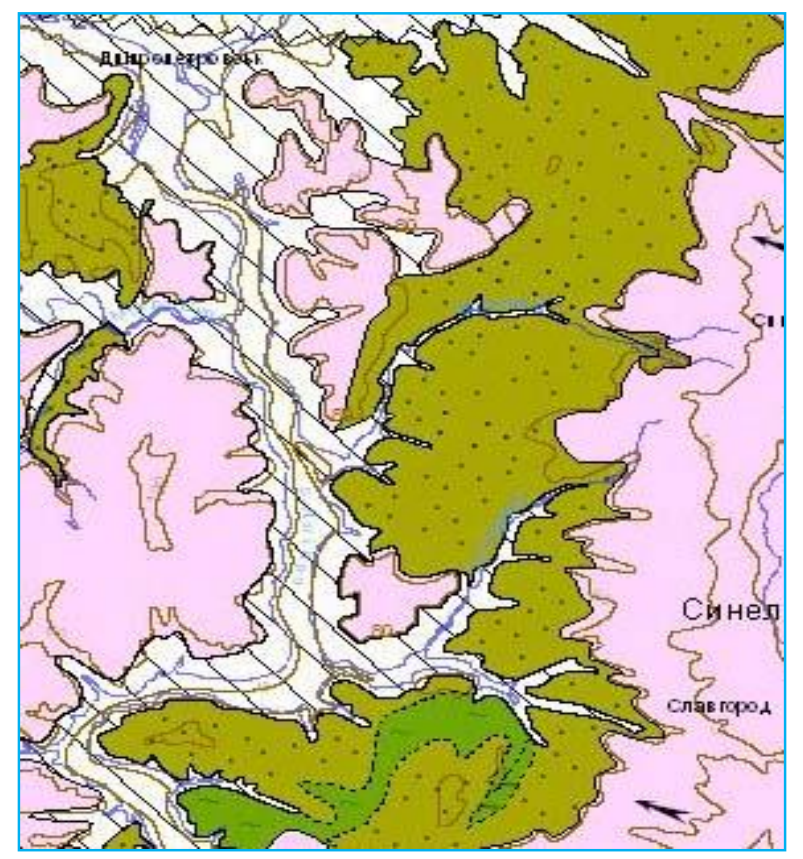

Mandrykivski Layers changes from $+40.0 \mathrm{~m}$ under the alluvium of the Dnipro, where they are partly washed out, to $63.0 \mathrm{~m}$ in the mostelevated areas ofthe paleodepressions, thickness of the layers - up to $18.0 \mathrm{~m}$.

Mezhyhirska suite is the terminal part of the Kharkiv suite and by the external signs of the rocks which it is composed of it is similar to clayey-sandy-aleurite rocks of the Obuhivska suite, on which it is embedded. In most sections, the contact between them is not always distinct,it is often gradual, without clear signs of interruption or wash-out. However, the presence of some sections of large clastic fragments in the bases of some sections, and uniform thickness of the suite over a large area, the lower extent of lithification and significant poverty of faunistic complexes compared to the Obuhivska suite allow mapping the Mezhyhirska suite as a separate geological body with distinct borders and distribution area. Shallow-water-marine deposits of the suite of homogenous lithological composition have a limited distribution within the mouth part of the Synelnykovo paleodepression of the Ukrainian Shield (north of the border of the RLP).

Miocene history of the RLP "Dniprovi Porohy" starts from the much more distributeddeposits, compared to Paleogene deposits, of the Novopetrivska suite of the Poltavska series. They are absent in the high areas of water divides (usually limited in the upper part by isohypse of the basement surface $+80.0 \mathrm{~m}$ ), in the valley of the Dnipro and other linear erosional forms, where they are washed out and partly alternated by alluvium (Fig. 4).

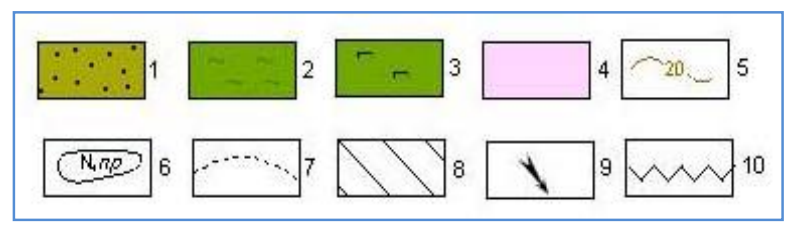

Fig. 4. Lithological-facies map of the distribution of the deposits of the Novopetrivska suite (Poltavska series). Lake facies: 1 - white quarzitic sands; 2 - insignificantly sandy clay; 3 - secondary kaolin; Other conventional signs: 4 - areas of denudation; 5 - stratoisohypses of the Pre-Middle Sarmatian surface; 6 - borders of distribution of the deposits of the Novopetrivska suite; 7 - facies border; 8 - orientations of transfer of terrigenous material; 9 - borders of SFZ. 
In the most complete sections, the Novopetrivska suite is divided into three subsuits - lower, middle and upper subsuites, in the Synelnykivska SFZ designating middle and upper subsuits in some sections is possible. Taking into account the non-uniform thickness of the lithological composition of the rocks of the Novopetrivska suite, its ranging in area and in section, insignificant thickness of the subsuits and absence, often, of distinct criteria for dividing suites into subsuits, it can be mapped within the territory of the RLP as an integral body, without division into subsuits. The rocks of
theNovopetrivska suite with notable stratigraphic rupture, with washout, are embeded on a relatively even Paleogene surface, and in places, where it is absent or washedout directly on the crystalline rocks of the basement or their weathering rind.

The lower subsuit comprises mostly evengrained poorly sorted quartzitic sands with interlayers of gravel and pebble. The sands are oftenwith angular unconformity, grey and ochreyellow, often clayey, with ferruginization on the surfaces of lamination (Fig. 5).
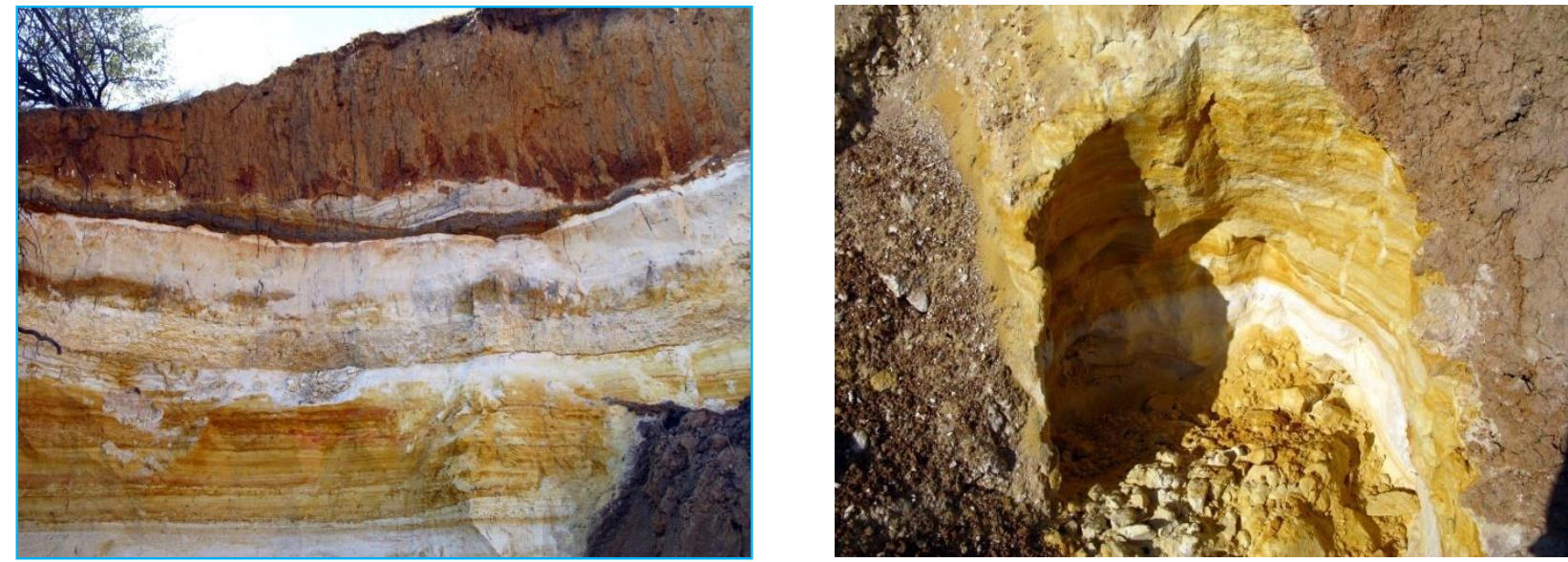

Fig. 5. Outcrops of the Novopetrivska suite in the Ploska Osokorivka Ravine

The sands of the Novopetrivska suite are related to the world's best Samotkan placer deposit of titanium and zircon, and within the studied territory, the lower subsuite is characteristic for the highest content of conditional ilmenite. In the peripheral areas of paleodepressions and on the slopes of the Ukrainian Shield, and in places of extrusion of the deposits of the Novopetrivska suite, the sands are alternated on the facies bydark-grey and black clays with lenses of brown coal and interlayers of kaolin clays. According to the data of differentialthermal analysis, clays of the lower subsuite are mostly kaolin and slightly kaolin, sometimes hydromicaceous-kaolin. According to the results of granulometric analysis of sandy rocks of the lower subsuite, a notable increase in the size of grains downwards is observed and the insignificant role of clayey and aleurite fractions was determined (5 to $17 \%$ ).
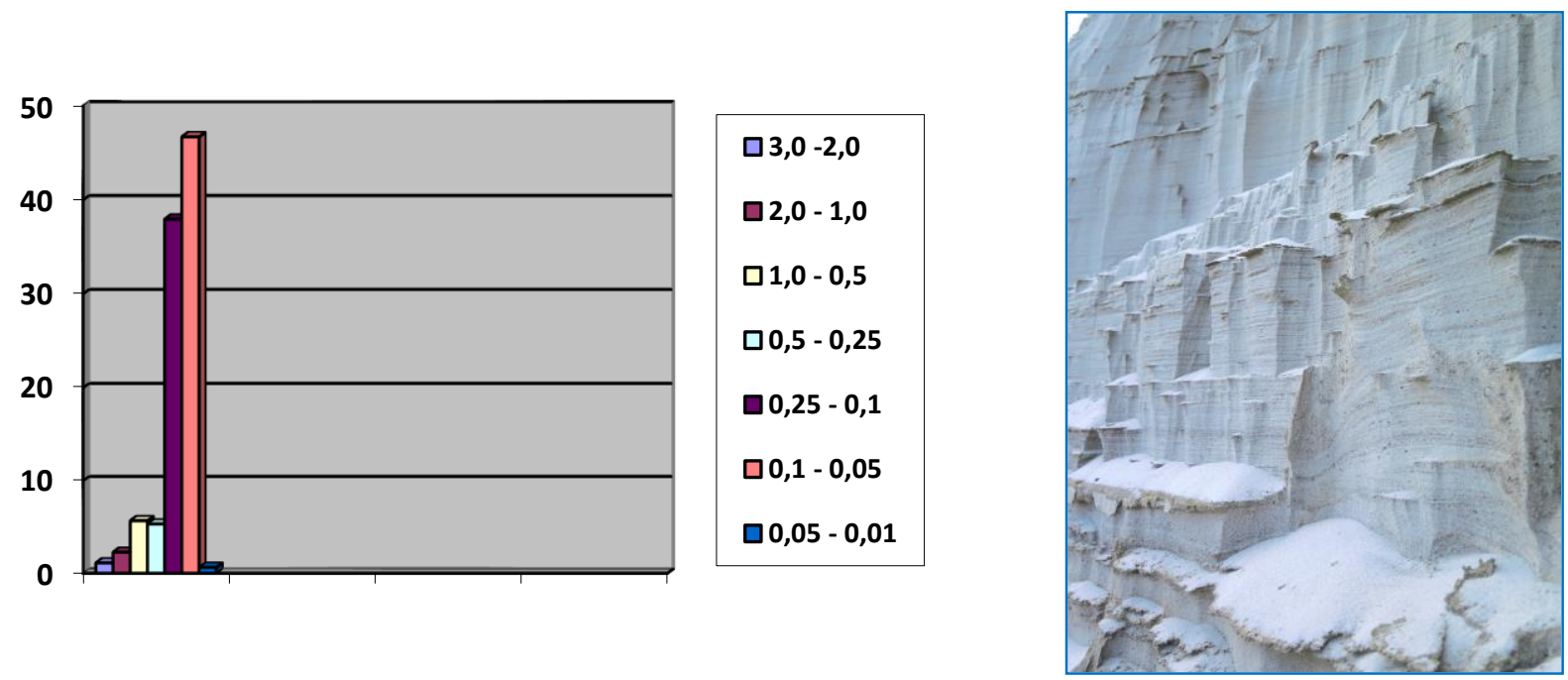

Fig. 6. Histogram of granulometric composition of the Novopetrivska suite and sands in the outcrop 
Sands of the middle subsuite are quartzitic (93.2\% of $\mathrm{SiO}_{2}$ ), in most sections, light grey to white, fine-grained, often to aleutites (85-95\% of aleurite fraction), well sorted, friable, homogenous, sometimes with notable horizontal lamination which is emphasized by ferruginization of the rocks or thin interlayers (up to $1-2 \mathrm{~cm}$ ) of light grey thin dispersive flexible clay. In the upper parts of the section, flint concretions of rounded form and their fusions can be found. In the areas remote from the central parts of the basins of sediment-accumulation and axis parts of paleodepressions, in the section of the middle subsuite, there occur interlayers of large-grained sands, gravel and pebble, grey and ochre-yellow clays of $0.5-1.5 \mathrm{~m}$; and the role of average-grained fractionincreases. On different levels of the section of the Middle subsuite, the sands are often enriched with ilmenite, rutile, zircon and other minerals, to accumulation of which many heightened mineralization points are related.

To the Upper Novopetrivska subsuite, a kaolin-sandy layer of rocks is related. The lower part of the subsuite is composed of quartzitic, kaolin, consolidated, fine- and average-grained sands of light grey colour, sometimes ferruginizated, yellow-ochre to brown-black, average sorted, often enriched with ore minerals. In the upper part of the section, the sands are most clayey, gradually replaced with kaolin clays which complete the section and form interlayers of $2.5 \mathrm{~m}$ thickness. The clays are mostly grey and light grey, but quite often are intensely ferruginizated, spotted, ochre, yellow-greenish and red-brown, non-homogenous, dense. In the border parts of the depressions, the section of the Novopetrivska suite often ends up with carbonaceous dark-grey and black clays with lenses of brown coal. A distinctive feature of the upper subsuite is that the sands contain nonuniform in thickness, non-thick (up to 0.8-1.1 m) interlayers, lenses and separate "boulders" of quartzitic, quite solid, sometimes quartz-like, often kaolin, light- and yellowish-grey fine- and average-grained homogenous sandstones (Fig. 7).
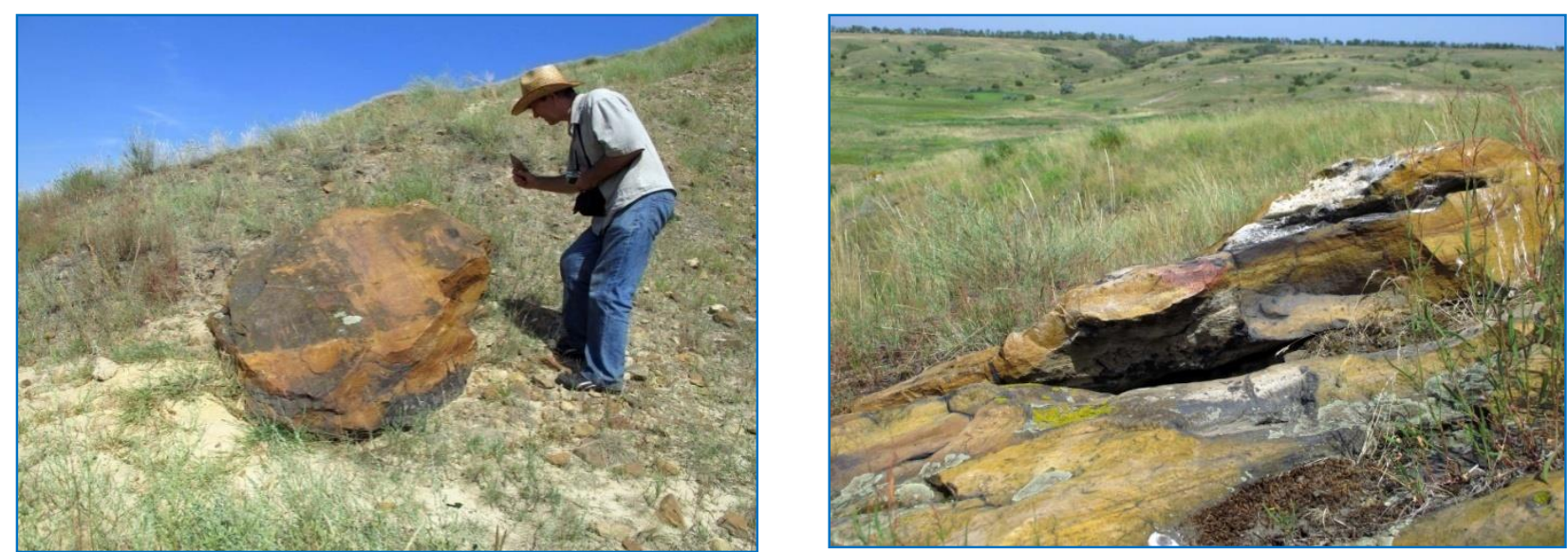

Fig. 7. Boulders of quartzitic sandstones with sands of the Novopetrivska suite
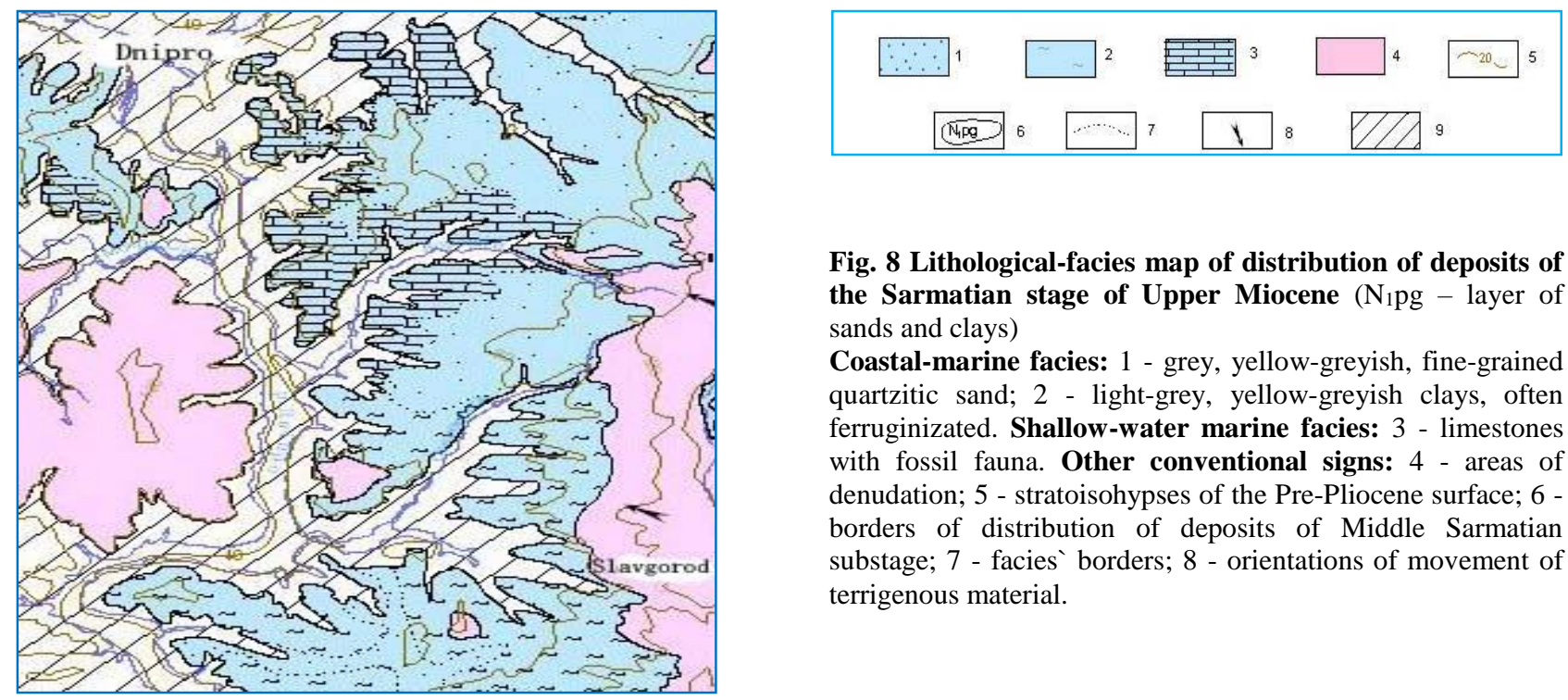

Fig. 8 Lithological-facies map of distribution of deposits of the Sarmatian stage of Upper Miocene $\left(\mathrm{N}_{1} p g\right.$ - layer of sands and clays)

Coastal-marine facies: 1 - grey, yellow-greyish, fine-grained quartzitic sand; 2 - light-grey, yellow-greyish clays, often ferruginizated. Shallow-water marine facies: 3 - limestones with fossil fauna. Other conventional signs: 4 - areas of denudation; 5 - stratoisohypses of the Pre-Pliocene surface; 6 borders of distribution of deposits of Middle Sarmatian substage; 7 - facies` borders; 8 - orientations of movement of terrigenous material. 
During the late Novopetrivsky period, a gradual contraction and shoaling of the fresh water basin of sedimentogenesis and restoration of the river network occur, which is indicated in the lithological composition of the rocks. Deposits of the Novopetrivska suite are characterized by poverty of organic remains, but within the studied territory, O. Davydova found a complex of Foraminifera: Haplophpragmoides kjurendagensis Morosova, Cyclammina pleschakowi Pischwanova, C. vul-choviensis Venglinski, Bulimina ex gr. aculata Orbigny, Reussella ex gr. spinulosa Reuss, Uvigerina sp., Rotalia ex gr. rota Kracheninnikov, $R$. toltransis Kracheninnikov, Discorbis pellucidus Krach., Pullenia bulloides sexacamerata Pischwanova, Allomorphina macrostoma Karrer, A. trigona Reuss, Cibicides sp.

On the territory adjacent in the west, within the Surska depression, similarly to the structure of the Prydniprovska depression, we found interesting facies of the Novopetrivska suite, which contain a complex of Foraminifera, studied by I. D. Konenkova (Konenkova, 1989). The compound of the complex, and especially, numerous endemic Discorbis figuratus Konen, allowed us for the first time to conduct a correlation of the Middle Novopetrivska subsuite with Karagan-Chokrak deposits of the Eastern Pontic littoral (Manyuk, 1996, 1997).

The upper Miocene subdivision is represented by deposits of the Sarmatian regional stage and undivided layer of mottled clays. The Sarmatian regional stage within the studied area is represented by a layer of sands and clays with notable role of limestones and mergels.According to the faunistic data, the layer of sands and clays corresponds to the Middle Sarmatian regional substage of the regional scale. The layer is distributed across the greater part of the territory, except the highest areas of the central part of the territory of the park and river valleys, where it was washed out over the Pliocene-Quaternary period. It is characteristic of mostly terrigenous composition with subordinatecarbonaceous interlayers in the overburden.

The lower part of the section of the layer of clays and sands comprises quartzitic sands, mostly grey, light-grey, yellowish-grey, greenish-grey (rarer), fine- and average-grained, averagely and well sorted, clayey in most cases, sometimes swollen and friable, often with distinct horizontal and angular lamination, in the overburden consolidated, more clayey, and ferruginizated to a different extent. Along with the described section in the right bank part of the valley of the Dnipro, a section is often found, where large-fragmented fractions dominate. There is often observed an alternation of large-grained sand, gravel on the one hand, and poorly sorted gravel of different extent of roundness, of ochre and brown-yellowish (up to red) colour, with characteristic angular lamination, rarer with diagonal and transversal, on the other hand. In the lower part, there are often found interlayers and lenses of light-grey flexible finely dispersed clay of 1-3 to $0.3 \mathrm{~m}$ thickness. The results of granulometric analysis prove the large diversity of granulometric fractions and sometimes complete absence of sortation.

The upper part of the section of the Middle Sarmatian rocks comprises clays, sandy and gritty clays, and carbonaceous rocks. The position of carbonaceous rocks with normal marine fauna in the upper parts of the layer indicates the ingression of the Middle Sarmatian basin into the terminal phase of marine sedimentogenesis within this territory. According to lithology, the carbonaceous facies are represented by limey clays, mergels and limestones. Limestones, the thickest part of which was found near Suha Kalyna village, are light-grey and yellow-grey organogenic or shell and chemogenic limestones of relatively low density, detritus and massive average-grained, often cavernous with numerous fragments of shells of Mactra (Sarmatimactra) fabreana Orb., $M$. sarmatimactra vitaliana Orb., Obsoletiforma obsoletiformis (Koles.), O. ustjurtensis (Andrus.), O. lithopodolica lithopolica (Dub.), O.pseudosemisulcata (Andrus.), Plicatiforma fittoni fittoni (Orb.), Dorsanum duplicatum (Sow.), Trochus sp., Musculus sp., Paphia vitaliana Orb., Gybbula sp., typical for Dnipropetrovski layers of the Bessarabian regional substage.

The remains of the Quarry in the Suha Ravine near the Suha Kalyna village is the only place in the Rapids part of the Dnipro, where one can see outcrops of Sarmatian limestones. The first reports on them are known from the work by Valerian Domger (Domger, 1902), where he writes: "Here, on the right side of the Voronaia, on the peasant land, limestone has been extracted in two places. Pits are now filled and the embedding of limestone is not seen, it is only clear that under the layer of grey-yellow clay of up to 2 sazhens thickness, clayey sands are embedded, oversaturated with Sarmatian shells. The commonest are Tapes gregariusandCardium fittoni,also there could be foundCardium obsoletum, Trochus podolicusand others. Lower lies the limestone". The old Quarry, or what is left of it, is considered as an object of geological heritage or a promising geological relic of nature (Fig. 8). 

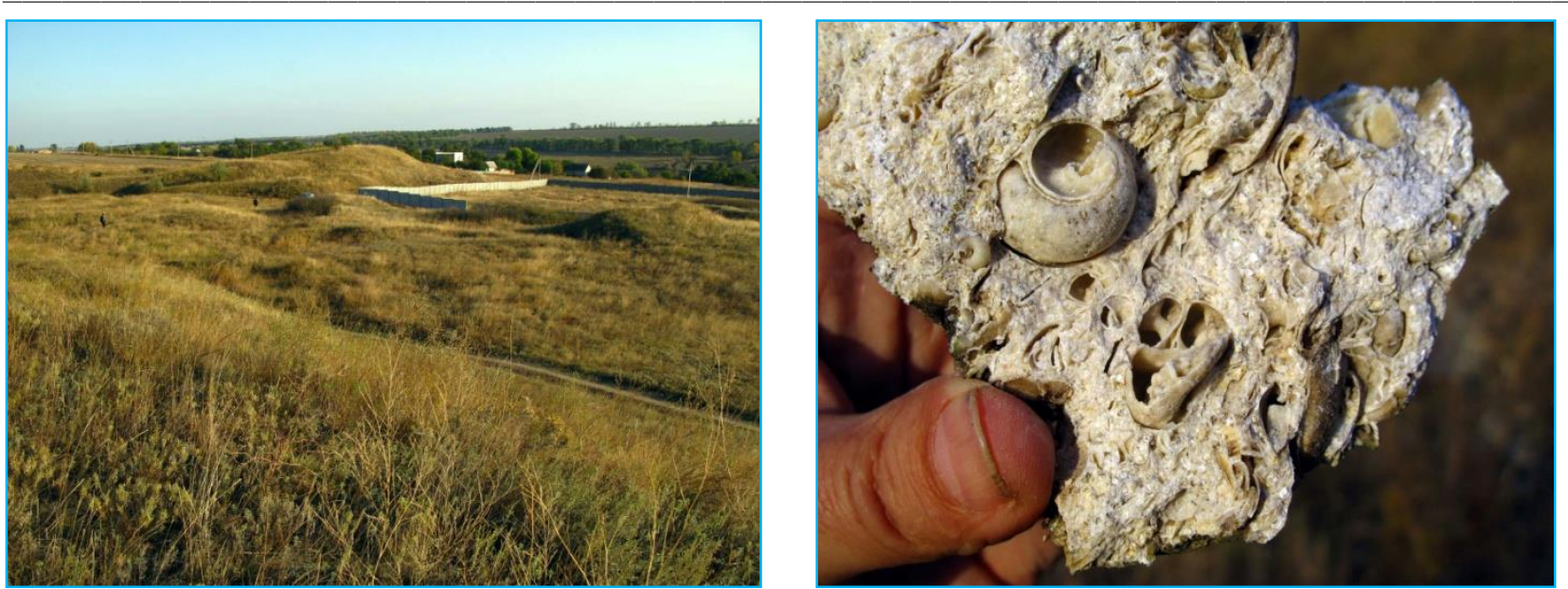

Fig. 9. Remains of the Quarry for extraction of Sarmatian limestones and a sample of limestone with nuclei of gastropods

In the rest of the territory, carbonaceous rocks are on the facies substituted with sandyclayey deposits of coastal-marine, lagoon and continental genesis. They are dark grey lowcarbonaceous, greenish-grey, and green, often intensely ferruginizated, sandy clays with lenses and interlayers of sands and quartzitic sandstones, usually consolidated. According to differentialthermal studies of the Middle Sarmatian clay, the dominating types are hydromicaceousmontmorillonite, kaolinite and, sometimes, kaolinite-hydromicaceous.

In addition to mollusks, a complex of Foraminiferans was found, typical for Middle Sarmatian stage: Triloculina volhynica Didkowski, Nubecularia novorossica Karrer et Sinzow, N. mut. crustaformisBogdanowicz, N.mut. deformis Karrer et Sinzow, Cibicides oischocorviensis Venglinski, Porosononion subgranosus Bogdanowicz, Rotalia sp.,Globulina $s p$. and others. A spore-pollen complex with clayey deposits of the Sarmatian stage is characterised by predominance of coniferous tree plants (up to 64\%), which compared to the Novopetrivsky period significantly dominate over the Taxodiaceaeand Cupressaceae. Tropical evergreen forms are present in the form of relics, the share of shrub and herbaceous plant groups notably increases.

The terminal part of the Late Miocene Early Pliocene section is the layer of mottled clay $\left(\mathrm{N}_{1-2} \mathrm{Sg}\right)$. It is a specific layer of mostly clayey rocks, with practically no faunistical remains, distributed in elevated (but not the highest) areas of the water-divide parts of the territory. It is embedded without a notable rupture and wash-out on faunistically characterized Middle Sarmatian deposits or more ancient rocks, where a notable unconformity between them was observed. Mottled clays are overlapped by redbrown Pliocene clays, Quaternary limestones or alluvium of terraces. Thus, the layer formed over time, when in the adjacent territories, in the conditions of marine sedimentogenesis, rocks of Upper Sarmatian, Pontian and Kimerian regional stages were accumulating. The homogenous lithological composition of the mottled clays and almost complete absence of most characteristic organic remains do not permit us to conduct a more thorough division of them, though attempts have periodically been made.

Mottled clays are greenish-grey, grey and even dark-grey with ochre-rusty, crimson- and cherry-red spots. The clays are usually finely dispersed, viscous, flexible, shimmeringon the fractures` surface, but often non-homogenous; can be largely dispersed, aleuritic and sandy, in the lower part - with additions of poorly rounded quartzitic and feldspar fractures of sizes of gravel. The most characteristic features of the mottled clay layer is their high gypsum content,high level of ferruginization, especially in the upper horizons, and presence of oolites, dendrite and swelling nest-like accumulations of manganese oxides. Usually distinct in the section is a reduction of the role of hydromorphism from the floor to the overburden layers. In the upper layers, the number of crystalls, aggregates and nest-like accumulations of gypsum significantly increases. In the lower part of the section, there are sometimes found low-carbonated plant remains, small carbonate concretions.

According to the data of $\mathrm{x}$-ray and thermographic surveys, clayey minerals are represented by beidellite and montmorillonite, more rarelyby hydromica and kaolinite, or their combination. Granulometric composition differs by non-homogeneity and along with clayey fraction $(63.6-83.1 \%)$, average-large grained sands and gravel (5 to $30 \%$ ) are found in notable amount at insignificant amount of aleurite and fine sand (2 to $10 \%)$. 


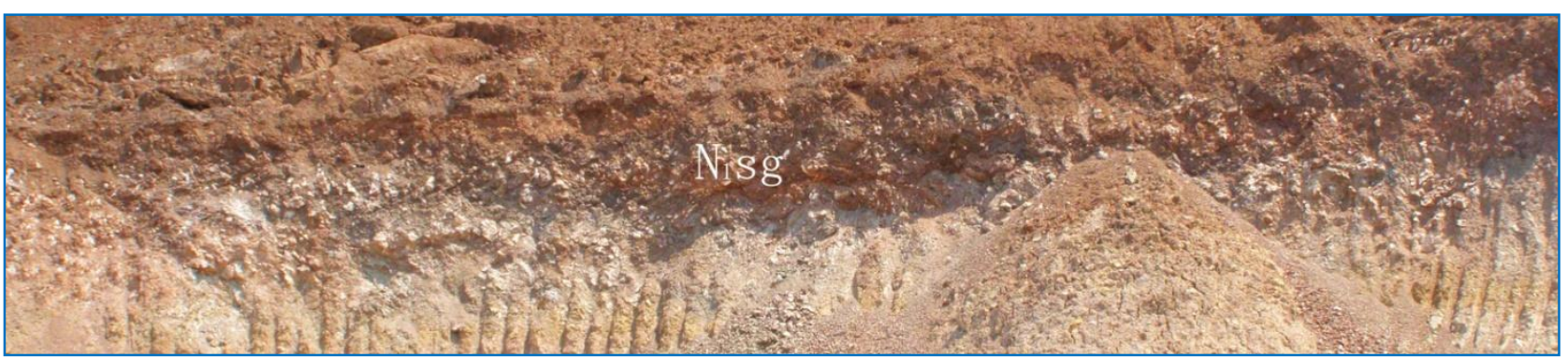

Fig. 10. Mottled clay with gypsum concretions

In the upper layers of mottled clays, scattered specimens ofMonodacna sp., Niritina $s p$., Hydrobia sp.are found. Specific spore-pollen complexeswere also found, where pollen of flowering plantsdominates, mainly broad-leaved tree plants: Quercus, Ulme, Pterocarya, Carya, Fagus, Acer, which equal 33-42\%. In small amounts, there were found tropical and subtropical flowering plants: Myrica, Nyssa, Ericaceae. ThePinaceaefamily is represented by Pinus, Picea, Tsuga, Podocarpus, Taxodiacea $(12.5-42 \%)$. All samples had the pollen of Chenopodiaceae (up to 9\%). Sometimes, a small amount of Politrichummosses were found.

Most researchers of mottled clays think that these clays accumulated in the conditions of shallow-water creeks, limans and lagoons of the Late Sarmatian and Pontian Seas. Enrichment in the Upper Part of gypsum indicates that the water regime of the water bodies was completely separated from the sea. The study of contemporary sediments of the lagoons, limans and coves indicate that the mottledgypsumbearing layer contains sediments of fresh-water as well as saline basins.

In the layer of mottled clays, with conformity, with no ruptures, a layer of redbrown clays $\left(\mathbf{N}_{2} \check{\mathbf{c g}}\right)$ is embedded. Thorough division of Quaternary deposits before climatoliths and distinct designation of the layer of mottled clays and mapping them on the area allowed us to find that the layer of red-brown clays comprises two horizons - Berehivsky and Siversky,with limited distribution in the studied territory. They are embedded with conformity on the mottled clays, at relatively high hypsometric levels $(+101.0 \mathrm{~m}$ to $+117.0 \mathrm{~m})$, and at lower levels $(+80-86 \mathrm{~m})$ in some areas of the territory, and have thickness over $8 \mathrm{~m}$ (4-6 $\mathrm{m}$ on average).

Siversky climatolith $\left(v d, l \quad \mathrm{~N}_{2} s v\right)$ is represented by clays of eolian-deluvialand lake origins, with limited distributiond in the southwest part of the territory as separate spots on relatively plain areas of post-Miocene surface of planation. The clays are brown- and pink-grey, light-grey with brown and red spots, largely dispersed, flexible, insignificantly consolidated, non-homogenous, limey, with rare carbonate concretions, often with oolites and dendrites of manganese oxides, in the lower part of the section - gritty. The clays` thickness is 2-4 m, rarely up to $6 \mathrm{~m}$, hypsometry of the surface ranges from 82 to $112 \mathrm{~m}$.

Berehivsky climatolith (e, al $\mathrm{N}_{2} b v$ )is represented by fossil soil distributed on the same area as the Siversky climatolith. It is composed of clays coloured bright-red-brown and dark-brown with redish tint, viscous, flexible, average- and large-dispersed, relatively homogenous, consolidated, low-limey, shimmering on the fractured surfaces, with characteristic dendrites and rare oolites of manganese oxides, often with dense carbonaceous concretions.For the transitional zone, at the contact with clays of the Siversky climatolith, typical features arelightness of colour, spottiness, sometimes grittyness.Thickness of the Berehivsky fossil fauna is 3-6 m.

Quaternary system. The surveyed territory is one of the most favourable in Ukraine for studying the continental deposits of the Anthropocene period and fossil fauna, first of all. Not surprisingly, a large amount of reference sections of Quaternary deposits is concentrated there. Within the region, the Starokodatsky section is located, which is stratotypic for the Kodak fossil fauna. Spasky, Taromsky, Havrylivsky and Ivanivsky referencesections are located outside the "Dnipro Rapids" RLP, but near it, which allows one to use the results of detailed surveys of these sections in designating the stratons of the studied territory. Detailed information on them can be found in studies by M. F. Veklich (Veklich, Artyushenko, Sirenko, 1967.

Eopleistocene substage is represented within the RLP by eolian-deluvial, eluvial, alluvial and lake deposits of lower and upper zvenos[Zveno is a stratigraphic unit of Quaternary system, suggested by Krasnov, that ranks lower than a substage or zone but higher than a horizon-Translator's note], which are embedded on red-brown Pliocene clays or older rocks. The lower zveno is represented by the Berezansky climatolith, the deposits of whichhave limited distribution on 
elevated areas of water-divides as clays of eoliandeluvial origin. The climatolith is mapped in the lower parts of the sections of elevated areas of water-divides, where it is represented by greybrown and dark brown spotted clays and limestones with carbonaceous concretions, rarely with crystals of gypsum, with notable signs of hydromorphism. They are no thicker than $4.5 \mathrm{~m}$. On the diagrams of gamma-ray logging, the limestones of the Berezansky climatolith are distinguished by lower activity.

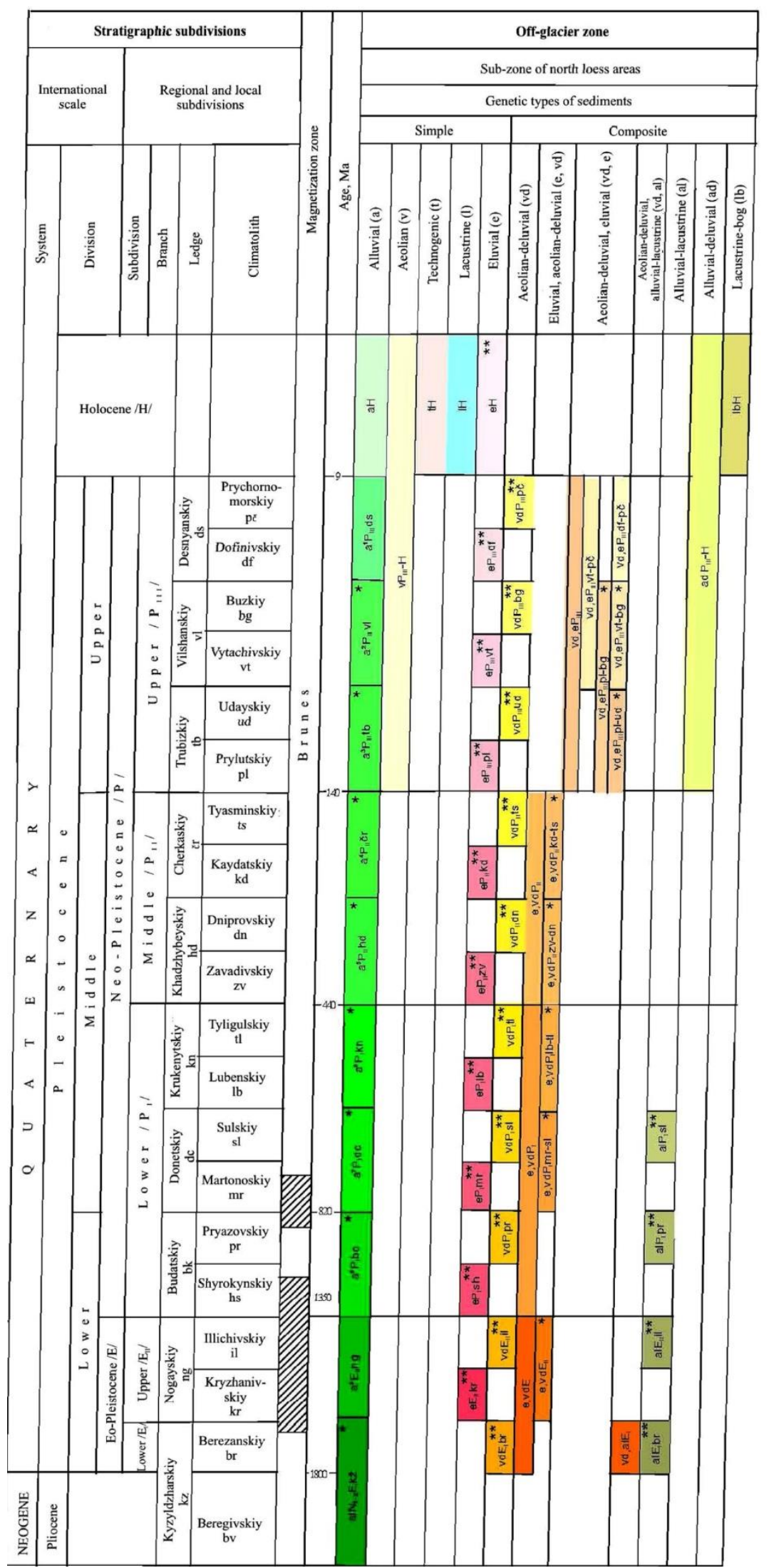

Fig. 11. Scheme of correlation of Quaternary deposits of the territory of the "Dniprovi Porohy" RLP 
The upper zveno. In the composition of the zveno, Kryzhanivsky (e EIlkr) and Illichivsky (vd EIIil) climatoliths are designated, which are represented by alluvial deposits of the ninth above floodplain terrace (Nogaisky step $a_{9}$ EIIng),eluvial and eolian-delluvial deposits. The Kryzhanivsky climatolith (e EIIkr).Subaerial deposits are distributed on a larger territory compared to the Berezanski deposits, both on water divides and elevated areas of slopes. On lower hypsometric levels, they occupy the lower part of alluvium of the ninth (Nogaiska) terrace distributed on the right bank of the Dnipro. This is the first from the bottom wellmarked fossil soil for this sheet, represented by redish-brown clays and dark-brown clays with redish tone with characteristic detritus and oolite oxides of manganese, with pnotable amount of swollen carbonate concretions. By compound, the clays are montmorillonite-hydromicaceous, with moderate addition of calcite (up to $5 \%$ ), highly clayey $(96.1 \%$ of the fraction $<0.01)$. The clays thickness is $2.5-3.2 \mathrm{~m}$, rarely up to $5.5 \mathrm{~m}$.

Illichivsky climatolith (vd EIIil). Eoliandelluvial deposits have a limited distribution, often completely altered by soil formation. The horizon comprises grey, greenish- and browngreyish clays and heavy loams of approximately even level of proportion of clayey and aleurite fraction, usually with notable amount of dense carbonate concretions, sometimes with ochreyellowish spots of ferruginization. The clays which are embedded in the overburden of the Nogaiska terrace are distinctive for having notable signs of hydromorphism, blue-grey color,gleyed, heightened amount of oolites of manganese oxides(al Elil). Clays are sandy in the lower parts, and gradually replaced by sand. Thickness of the climatolith equals $1-3.7 \mathrm{~m}$, rarely up to $6.2 \mathrm{~m}$.

Nogaiska step - $a^{9}$ EIIng. Alluvial deposits of the ninth terrace have limited distributionon the Right Bank of the Dnipro from the mouth of the Mokra Sura River in the north to the mouth of Bashmachka Ravine in the south. It has outcrops on the shores of the Dnipro in the south-west part of the territory. Alluvium is represented by light grey and yellowish-grey quartzitic fine- and average-grained sands with addition of gravel at the base of the layer. Thickness of the sands equals 8-12 m.

The Neopleistocene part is divided into three zvenos: lower, middle and the upper. The lower zveno is represented by the sediments of alluvial (Budatsky, Donetsky and Kruzhenytsky steps [step is a stratigraphic unit of sediments of Quaternary system; it distinguishes complexes of rocks, formed over global and subglobal cooling or warming of a climatolith - Translator`s note]) and overlappings of eluvial, eolian-delluvial and complex genetic types, which is conditioned by phases of the development of the territory. Six climatoliths are designated in the section of the lower part.

Alluvium deposits form the Budatska $\left(a^{8}\right.$ PIbk), Donetska (a $a^{7}$ PIdc) and Krukenytska $\left(a^{6} P I k n\right)$ terraces. They are not manifested in the relief. The deposits have become exposed by boreholes outside the RLP territory in the valley of the Dnipro from the mouth of the Samara and further to the north. Subaerial eluvium and eoliandelluvial deposits are mapped as non-divided formations of the lower zveno(e,vd PI). In the section of this zveno, six climatoliths are designated. Shyrokinsky climatolith(e PIsh). Shyrokinsky fossil soil is the most distributed in the region.It is absent only in deeply cut erosional valleys. The overburden is embedded at the level of $69.0 \mathrm{~m}$ to $159.0 \mathrm{~m}$. A typical section has been studied near the Topol housing complex in Dnipro (borehole 414). They are mostly clays and heavy loams of hydromicaceous-montmorillonite composition with dark brown colour with reddish tone and of red-brown colour, with carbonate concretions. According to the chemical analysis, the clays and loams differ from other horizons of eolian-delluvial and eluvium origin by lower content of $\mathrm{CaO}(5.8 \%$ ) and $\mathrm{SiO} 2$ (to 55.0 $\%)$.Shyrokinsky soil is characterized by heightened gama-activity compared to the Pryazovsky and Illichivsky horizons. Its thickness is 1.4-6 m. Pryazovsky climatolith (vd PIpr).Eolian-delluvial deposits of theclimatolithhavevery limited distribution; on most of the studied territory, they are almost completely altered by Marton soil formation. The deposits are represented by dark brown-grey and light brown heavy limey loam of large-alleurite structure of $0.4-1.5 \mathrm{~m}$ thickness (rarely up to 3.8 $\mathrm{m})$. A typical section is located in the Sazhavka Ravine (Stari Kodaky).

Martonovsky climatolith (ePImr). Eluvial loams of the climatolith form one of the most well marked and widely distributed horizons. Loams are dark brown with red tone, slightly limey, with films and oolites of manganese oxids, with heightened content of clay, with signs of hydromorphism on the terraces. A typical outcrop can be found in the Starokodatsky referencesection. Thickness of the deposits is 2.0$5.6 \mathrm{~m}$. Sulsky climatolith (vd PIsl).Eolian-deluvial deposits of the climatoliths occur fragmentally in particular sections of the Prydniprovska uplands. Yellow- and brown-red loess-like heavy loams of fine-aleurite structure, of shell окремості, with 
single carbonate concretions.By granulometric composition, it belongs to large aleurite (80.7 $86.8 \%$ of aleurite fraction). In the deposits of the climatolith, there were found remains of terrestrial mollusks: Pupilla muscorum (L), Succinea oblonga D r a p., Vallonia tenuilabrisA 1. B r.). Thickness is 0.3-2.2 m. TheLubensky climatolith ( $e$ PIlb)is represented by a suite of fossil soils, the most typical section of which was found in the Bili Perehony Ravine (Sazhavka) and borehole 414. Loam is brown to dark brown, sometimes with reddish tone, average, consolidated, microporous, limey, with small carbonate concretionsin the foot. The dominating part in the loams is clayey fraction (38-55\%); aleurite and sandy fraction, equalling 16-23 and 2-8 \% respectively.Chemical composition of the rocks differs by much lower content of $\mathrm{SiO} 2(59.3 \%$ on contrast to $74.6 \%$ in loess of the Dniprovsky climatlith), increased values of all other oxides except $\mathrm{TiO}_{2}$ and alkali which are more numerous in soil. Thickness is 1.3-4.8 m. In some sections, loams include fragments of shells of Helicella and Cepaea genera.

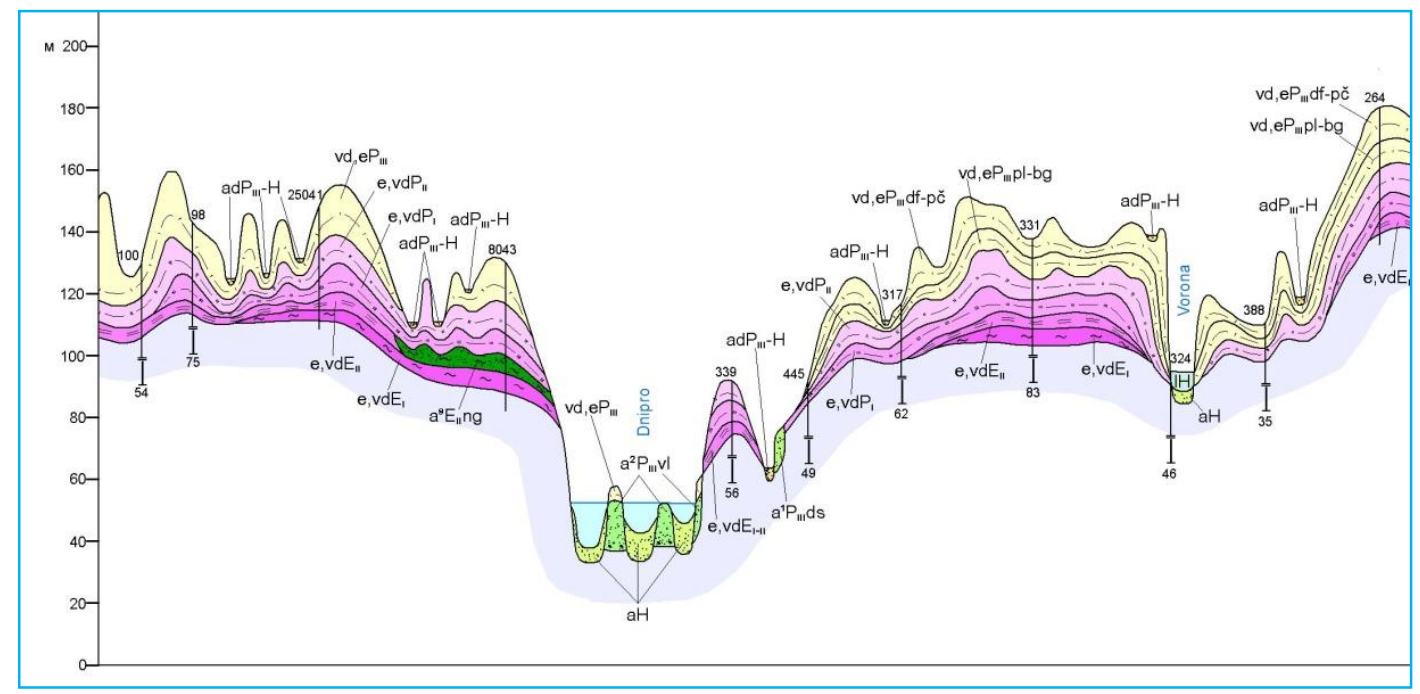

Fig. 12. Geological section of Quaternary deposits in the valleys of the Dnipro and the Voranaia rivers

Tylihulsky climatolith ( $v d$ PItl) is represented by loess-like average loams of dark yellow and pale yellow-reddish-brown colour, swollen, loamy, in lower parts - gleyed loams. In the rock, fine aleurite fraction(54-61\%); clayey - 16-22\% and sandy - $1.4 \%$ dominate. In spore-pollen complexes, a small amount of Chenopodiacae and Artemisia is present. Often, there are boreal mollusks Vallonia tenuilabris Al. Br.). Alluviallake Tylihulski facies form the upper part of the Krukenytska terrace, where they are represented by dark brown consolidated clay with intersections of clayey sand. Thickness of the climatolith is 0.3-2.0 $\mathrm{m}$, rarely up to $4 \mathrm{~m}$; height above the sea level is 79.0-152.0 m.

Middle zveno is represented by alluvial (Hadzhybeisky and Cherkasky steps), eluvium, eoalian-deluvial and complex genetic types. Hadzhybeisky step ( $a^{5}$ PIIhd). Deposits of the fifth terrace form a stripe on the left bank of the Samara, where the outcrops are exposed in the Rybalsky Quarry. By the content, these sands are quartzitic, clayey, yellow-grey, fine-grained and greenishgrey clays and loams with total thickness of up to $12.0 \mathrm{~m}$. Cherkaskystep (a PIIcr $)$.Deposits of Quaternary terrace are characterized by broader distribution compared to the old terraces and occur in the valley of the Dnipro. Lithologically, they are quarzitic sands of light grey and light greenish-grey colour with numerous spots of iron hydrooxides, swollen, fine- and large-grained, with addition of glauconite in the lower parts. Thickness of aluvium is 5.6-7.4 m. In the deposits of the Cherkaska terrace, according to $\mathrm{P}$. K. Zamorii, numerous shells of the following species were found Vivipara fagiata $\mathrm{M}$ u 1 1., Lythoglyphus naticoides $\mathrm{F}$ e r., Fruticicola hispida L., Succinea pfeifferi R o s s., Bithynia leacht troscheli $\mathrm{P}$ a a s $\mathrm{ch}$., and also bones ofVulpes lagapus meridionalis (Zamoriy, 1961).Eluvium and eolian-deluvial deposits (e,vd PII) are distributed across most of the area; absent in river valleys, gullies and ravines. Represented by Zavadivsky and Kodatsky fossil soils which are distinct in clear signs of marking horizons and thick Dniprovsky and Tiasmynsky loess loams.

Zavadivsky climatolith (e PIIzv).Fossil soil of the climatolith is the bestdistributed and distinguished in this section. In most reference sections, it is represented bya complete suite of soils: initial stage, climatic optimum and terminal stage. It is a heavy limeyloam of dark brown colour with red tone and of light reddish-brown colour. According to chemical analyses, Zavadivski loams differ from the bedding and overlying loess 
formations by heightened content of all oxides, except $\mathrm{CaO}$ and $\mathrm{SiO}_{2}$, which are characterized by reduced content. Contains single mollusks of Cuccineae oblonga D $\mathrm{r}$ a p., Pupilla muscorum (L.), P.sterri $\mathrm{V}$ o $1 \mathrm{t} \mathrm{h}$. Thickness of the climatolith is $1.0-3.0 \mathrm{~m}$, rarely up to $4.1 \mathrm{~m}$. Dniprovsky climatolith (vd PIIdn). Eolian-deluvial deposits are represented by loess and loess-like loams, distributed on elevated areas of the water divides. It is considered a reliable horizon marker and is the thickest among the Quaternary climatoliths. The main bearing sections are Starokodatsky, Krasnopilsky and section of borehole 414. They are loess and loess-like loams of pale yellow-reddish colour, swollen, average-grained, macroporous, fine-aleurite, with carbonaceous mycelia. According to the data of chemical analysis, they are characterized by heightened content of $\mathrm{SiO}_{2}(67.0$ $\%$ compared to $59.7 \%$ in the Zavadivsky soil) and $\mathrm{CaO}$ (6.3 to $13.8 \%)$ and reduced content of all other components. Differential-thermal analysis indicates the hydromicaceouscomposition of the loam. Thickness of the deposits is from 1.8-4.5 m in most of the sections to $8.3 \mathrm{~m}$ and even $12.3 \mathrm{~m}$.

Kodacsky climatolith (ePIIkd).Fossil soil is considered an important marker due to its distinctive colour, specific content and broad distribution. It is represented by a suite of soils; by two soils on the interfluves and three in the lowlands. In the studied area, a stratotype of horizon is located, designated by M. F. Veklich (Veklich, 1968) in Bili Perehony Ravine (Sazhavka) in the Stari Kodaky village. In the typical section of borehole 414 in Dnipro, under the Tiasminsky loess, in 10.5-19.0 m interval, a suite of Kaidatski fossil soils is embedded, composed of the upper layer of soil of terminal stage, of $11 \mathrm{~m}$ thickness and soil of the stage of climatic optimum of $3.6 \mathrm{~m}$ thickness. Total thickness of the climatolith is $8.5 \mathrm{~m}$, which corresponds to its thickness in the bearing Kodatsky section, where it is represented by a complete series of soils. In the rest of the territory, its thickness ranges from 0.6 to $5.3 \mathrm{~m}$. Represented by greyish dark brown and dark brown-grey chernozem limey loam with notable thin horizontal lamination, with numerous carbonate mycelia; and with relics of Dniprovsky loess in the lower part. Soil is $97.5 \%$ composed of clayey, mostly hydromicaceous fraction. Similarly to other soils, it is characterized by lowered content of $\mathrm{SiO}_{2}$. Soils of the stage of climatic minimum are different by heightened content of humus, the amount of which reaches $0.3-0.49 \%$.Soil contains mollusks of mostly forest-steppe and steppe species: Chondrula tridens M u 1 1.), Siraphoruscf. moltschanovi $\mathrm{L} \mathrm{i} \mathrm{k} \mathrm{h}$. et $\mathrm{R} \mathrm{o} \mathrm{m} \mathrm{m}$ and others. The age of the Kodatsky buried soil, determined using the thermo-luminescent method, ranges in the interval of $260-150$ thousand years. However, such age was determined not by all explorers of the Quaternary deposits. Among them were those who consider it significantly younger (Herasimenko, 2004, Barshscevsky, 1989; Melnychuk, 2004) and those who consider the age of soil to be much older (Shovkoplias,1898; 2007). In 2011, V. H. Panyzych, using a method of radiocarbon dating, came to the conclusion that age of Kodatsky fossil soil is only 37.6 thousand years (Pazynych, 2011). Despite a variety of theoretical thoughts and fantasies around this topic, common sense suggests that the problem lies in the inaccuracy of the existing methods of determining the age of rocks. Ranging in the age determined, for example, for the Kodatsky soil using the thermoluminescent method and radiocarbon methods is around 140-150 thousand years, which is rather frustrating. The principles of radiocarbon dating, developed by Williard Frank Libby, are currently coming under criticism, especially regarding their accuracy. And the most important aspect is that it has been persuasively proved that the age of objects older than 50,000 years is theoretically impossible to determine using the radiocarbon method (How accurate is the radiocarbon method?, 2018). However, it is a topic foranother discussion and requires further studies and searching the solution for this problem.

Tiasmynsky climatolith ( $v d$ PIIts).Eoliandelluvial deposits of the climatolith in most of the sections are altered by the Plylutsky soil formation and occur sporadically as thin loess loams of pale yellow-reddish, light brown and brown-pale yellow-reddish, macroporous, fine-aleurite with carbonaceous mycelia. According to the data of granulometric analysis, loams are in approximately equal amount composed of fine (32.8\%) and large (31.5\%) aleurite with notable amount of clayey fraction (12,7-12,9\%) and insignificant addition of sand (1.7-3.7\%). Among the mollusks, important are Vallonia tenuilabris A t. B r.), Vertigo parcedentata $\mathrm{S}$ a $\mathrm{n} \mathrm{d} \mathrm{b}$. Thickness of loams is 1.8$3.7 \mathrm{~m}$.

Upper zveno. Represented by alluvial, eluvial and eolian-deluvial formations. Alluvium deposits of the zveno are mapped in the range of the Trubizky ( $\left.\mathrm{a}^{3} \mathrm{PIIItb}\right)$, Vilshansky ( $\left.\mathrm{a}^{2} \mathrm{PIIIvl}\right)$ and Desniansky (aPIIIds)steps manifested in the relief as terrace plots and determined in all rivers of the territory. Terraces are composed of differentgraded sands of yelowish, grey-yellow and lightgrey colours, of 10-15 m thickness.

Trubizkyi ( $a^{3}$ PIIItb). Aluvium deposits of the third terrace are distributed in the valley of the Mokra Sura, Ploska Osokorivka,Vorona and 
Dnipro rivers. They are represented by yellowishlight brown sand, fine-grained in the upper part, becoming large-grained downwards. The upper part comprises greenish-grey and dark grey, often gritty clays and clayey sands $(1.5-2.5 \mathrm{~m})$. Thickness of alluvium is $8-8.6 \mathrm{~m}$.

Vilshanska step ( $a^{2}$ PIIIvl). Alluvium of the second terrace is distributed in large areas of all of the rivers and large old ravines, where they are fragmentarily stretched as two narrow stripes. Alluvium-quarzitic sand, grey, greenish- and yellow-grey with ochre-brown spots, swollen, finegrained, well sorted.Lake-floodplain, mostly greypaleyellow-reddish and brown loams and loamy sand with lenses and interlayers of quartzitic sand. Thickness of the alluvium is 7.0-10.0 m.

Desniansky step (aPIIIds). Alluvium deposits of the first above-floodplain terrace are composed of fine-grained silty and loose sands with interlayers of greenish-grey silty sandy loams and silts. Facies of stream beds are average- and large-grained sands. Alluviumincludes shells of Dreissensia, Lithoglyphys, Adacna, Unio, Valvata, Planorbisand others. Thickness of deposits is $6-11$ $\mathrm{m}$.

Eluvial and Eolian-delluvial deposits of upper Neopleistocene (e,vd PIII) rocks are distributed in the whole area of the sheet. Represented by alternation of loess horizons and fossil soils.They are mapped within two stratons composed of mostly eolian-deluvial sediments(vd,e PIIIpl-bg) and (vd,e PIIIdf-pč). On the right bank of the Dnipro, the zveno is divided. In the sections of the first straton, four climatoliths are designated (Prylutsky, Udaisky, Vytachivsky, and Buzky), and two are designated in the second (Dofinivsky and Prychornomorsky). The first straton corresponds to the united (non-divided) Trybizka and Vilshansky steps, and the second corresponds to the Desniansky step.

Prylutsky climatolith (e PIIIpl). One of the most widely distributed fossil soils within the sheet. Sometimes, along with Kaidatsky soil, it forms an integral layer as a result of alteration of Tiasmynsky loess. A typical section can be observed in the Starokodatsky and Taromsky outcrops, and also in the Rybalsky Quarry in the mouth of the Samara river. Represented by grey, dark grey with brown tone and light brown, swollen and insignificantly consolidated, limey loams. The Prylutsky loam, is characterized by heightened content of humus $(0.4-0.48 \%)$, aleurite granulometric content $(25-33 \%$ of fine laurite fraction, $27-41 \%$ of large aleurite, $19-23 \%$ of clayey and 1.1-2.0 \% of sandy fraction, Thickness of deposits is $1.8-4.2 \mathrm{~m}$.
Udaisky climatolith (vdPIIIud). Along with Dniprovsky and Buzky, itbelongs to the thickest loess horizons distributed in most of the sheet's area. Represented by light yellow-pale yellowredish limey, macroporous loess and loess-like loams, shelled, in the lower parts having small carbonate concretions. Thickness of the horizon is 0.5-2.2 m, more rarely - up to $4.0 \mathrm{~m}$. According to the results of chemical analysis, the loam is characterized by heightened content of $\mathrm{SiO} 2$, compared to the Vitachevsky and Prylutsky soils, but reduced content of all other oxides, except alkali, content of which is slightly higher. Contains remains of Succinea oblonga D r a p., Pupilla muscorum L., Columella columella $\mathrm{M}$ a $\mathrm{r}$ t. mollusks.

Vitachevsky climatolith(e PIIIvt). In most bearing sections, is represented by a suite of two fossil soils - upper and middle soils of terminal stage and stage of climatic optimum. Usually they are loams coloured in light and dark brown with red tone and dark brown-grey and red-brown, of prismatic shape, limey, notably consolidated, with signs of gleying in the lower parts, often spotted, non-homogenous. The sSoil has a slightly reduced content of humus. According to differentiationthermal analysis, the clayey component of the loam is significantly hydromicaeceous with signs of organic matter. Chemical composition of the soil is characterized by heightened content of all oxides except $\mathrm{SiO} 2$ (59.6\% compared to $70.0 \%$ in the Buzky horizon), and slight reduction of total of alkali, carbon dioxide. Thickness of deposits equals 0.7-3.5 m.

Buzkyclimatolith (vdPIIIbz). Is characterized by broad distribution within the studied territory.Thoroughly studied in the Starokodatsky bearing section and in the Rybalsky Quarry.The climatolith comprises loess-like, pale yellow-reddish and light reddish, lightweight, homogenous loams, which are macroporous, swollen and slightly consolodated, grey in the upper parts, with signs of soil formation, with carbonate concretions in the lower parts. Chemical composition is characterized by reduced amount of most oxides compared to the layers embedded higher and lower, except silica, calcium oxide and alkali. In diagrams of gammacarrotage, the Buzky climatolith is different by reduced parameter of radioactivity. Thickness of deposits equals 3-6 m. Among mollusks in loams, ubiquists dominate.

Dofinivsky climatolith (e PIIIdf). In most bearing sections, it is represented by a suite of two fossil soils - upper $\left(\mathrm{df}_{3}\right)$ and middle $\left(\mathrm{df}_{2}\right)$ soils.It is distributed practically ubiquitously, except the valleys of the rivers and ravines, where they are substituted with alluvium of the first terrace. It is 
represented by loams coloured light brown, sometimes grey with brown tone, often with distinct illuvial horizon of almost white colour. Thickness of the climatolith`s deposits is insignificant $(0.8-1 / 9 \mathrm{~m}$, rarely $3.0 \mathrm{~m}$ ). Mollusks are represented by numerous ubiquists: Helicella (Helicopsis) instabilis R., $H$. candicans L.P f r., Chondrula tridens $\mathrm{M}$ u 11 .) and others.

Prychornomorsky climatolith (vd PIIIpč). Eolian-deluvial deposits have a rather limited distribution .A typical section can be found within the Starokodatsky and other outcrops. Deposits are brown-pale yellow-reddish, brown-grey-pale yellow-reddish and yellow-pale yellow-reddish loess-like loams. Usually the loams are limey, macroporous, of prismatic shape, swelled and slightly dense, of aleurite content with equal proportion of fine $(37.7 \%)$ and large $(32.1 \%)$ aleurite and with notable amount of clayey fraction $(35.1 \%<0.005 \mathrm{~mm})$. Chemical composition of the Prychornomorsky loess and loess-like loams is characterized by heightened content of $\mathrm{SiO}_{2}$ compared to the fossil soil and $\mathrm{CaO}$, and reduced content of all other oxides except for alkali, the content of which changes irregularly. The layer's thickness is $1.0-3.0 \mathrm{~m}$. In the bearing sections, the following mollusks were identified: Chondrula tridens $\mathrm{M}$ u 1 l., Pupilla sterri $\mathrm{V}$ o $1 \mathrm{t}$ h., $P$. muscorum L., Cuccineae oblonga D r a p., Vertigo parcendetata $\mathrm{S}$ a $\mathrm{n} \mathrm{d}$ b., Vallonia tenuilabris A 1. B r.).

Upper Pleistocene and current zvenos are not divided. Alluvium-deluvial deposits (adPIII-H) fill the beds of small rivers, ravines, gullies with temporary water flows. In content, the deposits are clayey, sandy clayey, and clayey, non-homogenous, poorly sorted, with addition of carbonate material. Thickness of deposits is $0.5-3 \mathrm{~m}$, rarely 5-7 m.

Holocene. Deposits of Holocene rocks are characterized by the highest diversity of genetic types, among which there are designated eluvium sands, alluvium of floodplains of river valleys, alluvial-deluvial deposits, lake facies of oxbows and artificial water bodies, lake-swampy deposits and technogenic formations.

Eluvium deposits $(\mathrm{eH})$ are represented by contemporary soils. The largest area is covered by common chernozems of low humus content with insignificant or average thickness $(0.2$ to $1.0 \mathrm{n}$, rarely larger). All soils, except soddy, sandy and saline, have high natural fertility. Their land capabilityequals 56-67 points.

Lake-swampy deposits (lb $\mathrm{H}$ ) lie in beds of floodplain and oxbowlakes and are clayey-silty formations of dark grey and black colours, often with addition of sandy fine-grained fractions, with alternation of clayey and sandy interlayers. Thickness of deposits is $0.3-1.5 \mathrm{~m}$.

Lake deposits $(\mathrm{lH})$ lie in beds of currentlakes in water divides, artificial water bodies, ponds, water reservoirs and are represented by silt, gyttja of dark grey and black colour, sandy loam and sand.

Alluvium deposits $(\mathrm{aH})$ are mapped in beds in rivers of the largest erosional forms within the studied territory (Dnipro, Sura, Voronaia, and other), where are represented by light yellow-grey quartzitic sands of thickness of 3-6 m, rarely up $10 \mathrm{~m}$. The sands are poorly sorted, average- and large-grained, with additions of gravel and pebble, clayey at some places; washedout in the remaining areas.

Technogenic formations $(\mathrm{tH})$ are distributed in areas of territories under anthropogenic load. They include sandspits, tombolos and artificial areas of shores of the Dnipro with construction, large highways, tailings of quarries for extraction of granite used for rubble,crushed stone and dams.

Conclusions. The magnificence of the Dnipro, full of legends and stories, cannot be imagined without the Dnipro Rapids. They leave nobody who had seen them and felt their power indifferent since the Ancient Greek. historian of the Vth century B.CHerodotus from Halicarnassus, the Byzantine Emperor Constantine VII Porphyrogennetos (reigned in 913-959), the French engineer and military cartographer Guillaume Levasseur de Beauplan (1600-1685) to Dmytro Yavornytsky (great enthusiast and populizer of the Rapids) and the skilled pilots of the Dnipro Rapids. Geodiversity along with biodiversity and the historicalarcheological component of the Dnipro Rapids became the reason for creating the Regional Landscape Park "Dniprovi Porohy". A need emerged to describe the geological structure of the territory, within which the park is located, leading to field geological surveys over 2017-18 and analysis of a great amount of archival and literature sources, including the works by the author. Previous results of the conducted studies on the geology of the Precambrian rocks of "Dniprovi Porohy" were published in early 2018 (Manyuk, 2018). This particular article outlines the Phanerozoic Eon of the RLP territory and is based on lithologic-facies, paleontological, stratigraphic and geomorphologic studies. The essential element in creation and further development of the "Dniprovi Porohy" RLP is the geological component, which is a significant reason for changing the status of the RLP into that of Geological Park in the future.

\section{References}

Amitrov, O.V. 1987. Paleogenovye morya Ukrainy, kak svyazuyushee zveno mezhdu moryami severa 
Zapadnoj Evropy i yuga SSSR. [Paleogene seas of Ukraine, as a link between the seas of the north of Western Europe and the south of the USSR]. Biostratigraphy and paleontology of sedimentary cover of Ukraine. Collection of scientific papers, 148-150 (in Russian).

Barbot de Marni, N.P. 1869. Geologicheskij ocherk Hersonskoj gubernii.[Geological essay on Kherson province]. St. Petersburg, Demakovatypography, X, 1-165. Retrieved from: https://ru.wikisource.org/wiki/РБC/BT(in Russian).

Borisyak, N.D. 1867. Sbornik materialov, otnosyashchihsya do geologii Yuzhnoj Rossii. [Collection of materials relating to the geology of southern Russia].V.1, Kharkiv University, Kharkiv, 122-130 (in Russian).

Didkovskij, V.JA., Zelinskaja, V.A., Zosimovich, V.JU. 1984. Stratigraficheskie podrazdelenija pogranichnyh jeocen-oligocenovyh otlozhenij Severnoj Ukrainy. [Stratigraphic units of the Eocene-Oligocene boundary deposits of northern Ukraine] Dokl.AN USSR. Ser. B. 8, 9-12.(in Russian).

Domger,V. O. 1902. Geologicheskie issledovanija v Juzhnoj Rossii v 1881-1884 godah.[Geological research in southern Russia in 1881-1884]. Works of Geolkom, V. XX, 1-187.(in Russian).

Domger, V.A. 1902. Geologycheskye yssledovanyja v Juzhnoj Rossyy v 1881-1884 godah. [Geological investigations in Southern Russia in 1881-1884]. Proceedings of the Geological Committee, vol. XX, 1, 1902, 127 - 130.(in Russian).

Dubois de Monperre, Frederik. 1843. Voyage autour du Caucase, chezles Tscherkessesetles Abkhases, en Colchide, en Géorgie, en Arménieeten Crimée, 6 Bände, Librairie de Gide, Paris, 1839-1849, mitzusätzlichem Atlas.

Guldenstadt, J. A, 1879. Dnevnik puteshestvija v juzhnuju Rossiju akademika Sankt-Peterburgskoj Akademii nauk Gildenshtedta v 1773-1774 g. [The diary of a trip to southern Russia by academician of the St. Petersburg Academy of Sciences Guldenstadt in 1773-1774], translated from the German M. Shugurov.Zapiski Odessa Society of History and Antiquities. V. 11,180228.(in Russian).

Gurov, A.V., 1882. K geologii Ekaterinoslavskoj i Harkovskoj gubernij.[To the geology of the Ekaterinoslav and Kharkov provinces].Kharkov, Printing House of Kharkov University, V. IV, 1446.(in Russian).

Gurov, A.V. 1888. Geologicheskoe opisanie Poltavskoj gubernii: otchet Poltav. gubern. Zemstvo. [Geological description of Poltava province: report Poltava. province Zemstvo]. Kharkov: Type. M.F. Zilberberg, 1-1011. (in Russian).

Kaptarenko-Chernousova, O.K. 1951.Kievskij jarus i jelementy ego paleogeogafii.[Kiev stage and elements of its paleogeography]. Publ. AN USSR, Kyiv, 1 - 178.(in Russian).

Klemm, M.F. 1875. Geologicheskie issledovanija mezhdu rekami Saksagan'ju i Kalmiusom.
[Geological research between the rivers Saksagane and Kalmius.] Kharkov,Univ. typ., [2], 121, FB A 156/469.(in Russian).

Kljushnikov, M.N. 1958. Stratigrafija i fauna nizhnetretichnyh otlozhenij Ukrainy. [Stratigraphy and fauna of lower tertiary sediments of Ukraine]. Kyiv, 1 - 549.(in Russian).

Kljushnikov, M.N. 1950. O polozhenii tak nazyvaemyh mandrykovskih sloev. [On the situation of the socalled Mandrykov layers]. Scientists zap. Kiev. State Un., Geol., 3, 83 - 90.(in Russian).

Konenkova, I.D. 1989. O nekotoryh vidah foraminifer iz chokrakskih i karaganskih otlozhenij Vostochnogo Prichernomor'ja (Juzhnyj sklon Ukrainskogo shhita). [On some types of foraminifera from the Chokrak and Karagan deposits of the Eastern Black Sea region (southern slope of the Ukrainian shield)]. Paleontol. Coll., Lviv, 1-18.(in Russian).

Konenkova, I.D., Manyuk, V.V., Bogdanovich, E.M., Korallova, V.V. 1995. Paleontologicheskaja harakteristika verhnejeocenovyh otlozhenij Srednego Pridneprov'ja.[Paleontological characteristics of the Upper Eocene sediments of the Middle Dnieper]. Dnepropetrovsk, DNTE of Ukraine, 1950, Uk. 95, 1-18.(in Russian).

Krutzsch, W., Lotsch, D., 1957: Zur stratigraphischen Stellung der Latdorfstufe im Paläogen. Geologie, Jahrg. 6, H. 5 - Akadernie Verlag. Berlin.

Levakovskij, I.V. 1872. Issledovanie osadkov melovoj i sledujushhih za neju formacij, na prostranstve mezhdu Dneprom i Volgoju. [The study of sediments of the Cretaceous and the formations following it, in the space between the Dnieper and the Volga]."Works about nature testers at Kharkiv University." V. 6-7, 1-73.(in Russian).

Manyuk, V.V. 1996. K probleme korreljacii paleogenovyh otlozhenij Juzhnogo i Severnogo rajonov Srednego Pridneprov'ja. [To the problem of the correlation of Paleogene deposits of the Southern and Northern regions of the Middle Dnieper region]. Collect., Kyiv, IGN NAS of Ukraine, 52-53.(in Russian).

Manyuk, V.V. 1996. K voprosu o rasprostranenii verhnejeocenovyh otlozhenij $\mathrm{V}$ predelah Srednego Pridneprov'ja. [On the issue of the distribution of Upper Eocene deposits within the Middle Dnieper region.] Ecosystems of the geological past of Ukraine. Kyiv, UHN NAS of Ukraine, 49-50.(in Russian).

Manyuk, V.V. 1996. Paleogeografichni rekonstrukciï umov sedimentogenezu $u$ paleogenovih ta neogenovih basejnah Seredn'ogo Pridniprov'ja. [Paleogeographic reconstruction of sedimentogenesis conditions in the Paleogene and Neogene basins of the Middle Dnieper]. The dissertation author's abstract of the candidate of geological-mineralogical sciences. Harkov, 1 -16. (in Ukrainian).

Manyuk, V.V. 1997. Novye dannye k probleme korreljacii srednemiocenovyh otlozhenij Severnogo i Juzhnogo rajonov Ukrainy. [New 
data on the correlation of Middle-Miocene deposits in the Northern and Southern regions of Ukraine]. Collect. "Biosphere and geological disasters". Kyiv, 55-56.(in Russian).

Manyuk, V.V. 2012. Mandrykivski verstvy - unikalna paleontologichna pam'jatka Jevropy. Mandrykivka strata is a unique paleontological monument of Europe. Paleontological research in the improvement of stratigraphic schemes of the Phanerozoic sediments: Mater. XXXIV session of the Paleontological Society of the National Academy of Sciences of Ukraine. (Dnipropetrovsk, May 28-31, 2012). 80 - 82.

Manyuk, V. 2018. Precambrian geological history of the Dnipro Rapids. Bulletin of Dnipropetrovsk University. Series: geology, geography. Dnipro, V.26 (1), 22, 121-134.

Naskolko tochen radiouglerodnyj metod datirovanija? 2018. [How accurate is the radiocarbon dating method?]. Retrieved from: https://masterok.livejournal.com/960949.html (in Russian).

Nosovskij, M.F., Konenkova, I.D., Barg, I.M., Bogdanovich, E.M. 1978. Novye mestonahozhdenija mandrikovskih sloev v rajone Dnepropetrovska i ih paleontologicheskaja harakteristika. [New locations of the Mandrikov layers in the Dnepropetrovsk region and their paleontological characteristics].Cenozoic stratigraphy of the Black Sea and Crimea. Dnepropetrovsk: DGU, 2, 40 - 48.

Pazynych, V.G., Manyuk, V.V. 2011. Rezultaty radiovuglecevogo datuvannja kodaskogo pohovanogo gruntu z balky Sazhavka (Stari Kodaky). [Results of radiocarbon dating from Kodak buried soil from the Sajawka draw (Old Kodaki)]. Kyiv. Retrieved from: http://geographica.net.ua (in Russian).

Pazynych,V.G., Manyuk, V.V., Stecyuk, V.V. 2011. Novejshie dannye o vozraste kodakskoj pogrebennoj pochvy i dneprovskogo valunnogo suglinka $(\mathrm{k}$ probleme stratigrafii verhnego plejstocena). [Newest data on the age of Kodak buried soil and the Dnieper boulder loam the problem of stratigraphy of the Upper Pleistocene)]. Archeology and the ancient history of Ukraine. - 6, Archeology: from sources to reconstructions. Kyiv,IA NASU, 86 - 90 (in Ukrainian).

Rozenberg, A. 2001. Vozmozhnosti ispolzovanija otolitov kostnyh ryb $\mathrm{v}$ paleontologii $\mathrm{s}$ primeneniem nekotoryh iskopaemyh kompleksov iz kajnozoja Juga Ukrainy. [Possibilities of using otoliths of bone fish in paleontology with the use of some fossil complexes from Cenozoic of the South of Ukraine]. Paleontological substantiation of stratons by Phanerozoic Ukraine. Kyiv, 5660.(in Russian).

Savenko, N.G. 1972. Novi dani pro stratygrafichne rozchlenuvannja paleogenovyh vidkladiv pivdenno-zahidnoi' chastyny Dniprovs'koDonec'koi' zapadyny (Kobyljac'ka ploshha). [New data on the stratigraphic dismemberment of the Paleogene deposits in the southwestern part of the Dnieper-Donets depression (Kobylyatskaya area)]. Reports Academy of Sciences of the USSR. Series: B, 4, 328-330.(in Ukrainian).

Schpylchak,V.O., Manyuk,V.V. 2006. Derzhavna geologichna karta Ukrainy masshtabu 1:200 000.Pojasnjuvalna zapyska. Arkush M-36XXXVI (Dnipropetrovsk). [State geological map of Ukraine scale 1: 200 000. Explanatory note.Sheet M-36-XXXVI (Dnipropetrovsk)]. Kyiv, (Ministry of Environmental Protection of Ukraine, State Geological Survey, State Enterprise "Southernukrheology"), 30-59. (in Ukrainian).

Sokolov, M.O. 1894. Fauna nizhneoligocenovyh otlozhenij okrestnostej Ekaterinoslava. 1. Fauna glaukonitovyh peskov Ekaterinoslavskogo zheleznodorozhnogo mosta. [The fauna of the Lower Oligocene deposits of the neighborhood of Yekaterinoslav. 1. The fauna of glauconitic sands of the Yekaterinoslav railway bridge]. Proceedings of the Geological Committee, V. IX, 3, St. Petersburg, 1 - 5 (in Russian).

Sokolov, N.A. 1905. Fauna molljuskov Mandrikovki. Mandrikovka mollusks fauna. Proceedings of Geolkom, New Series, Issue 18, $1-82$ (in Ukrainian).

Stefanskij, V.L. 1987. K izucheniju fauny molljuskov mandrykovskih sloev Chaplinskogo kar'era (Dnepropetrovsk). [Study of the mollusk fauna of the Mandrykovsky layers of the Chaplinsky quarry (Dnepropetrovsk)]. Biostratigraphy and paleontology of the sedimentary cover of Ukraine. Kyiv, Naukova Dumka, 160-162. (in Russian).

Veklich, M.F., Artyushenko, A.T., Sirenko, N.A. 1967. Opornye geologicheskie razrezy antropogena Ukrainy.[Standard geological sections of the anthropogene of Ukraine]. Kyiv, Naukova Dumka, 1-107 (in Russian).

Veklich,M.F. 1968. Stratigrafija lessovoj formacii Ukrainy i sosednih stran.[Stratigraphy of the loess formation of Ukraine and neighboring countries]. Kyiv, Naukova Dumka, 1-288(in Russian).(in Russian).

Zamorij, P.K. 1962. Chetvertynni vidklady Ukrai'ns'koi' RSR. [Quaternary deposits of the Ukrainian SSR]. 1, Kyiv, KNU, 35-45. (in Ukrainian).

Zuev, V. F. 1787. Puteshestvennyja zapiski Vasilja Zueva ot S. Peterburga do Hersona v 1781 i 1782 godu. [The travel notes of Vasily Zuev from St. Petersburg to Kherson in 1781 and 1782]. St. Petersburg: At the Imperial Academy of Sciences, 1787. 1 - 273.(in Russian). 